\title{
EU Eastern Enlargement :Economic Effects on New Members 2000 2012
}

\author{
Miroslav N. Jovanović \\ University of Geneva, Geneva, Switzerland \\ Jelena Damnjanović \\ Novi Sad School of Business, Novi Sad, Serbia
}

\begin{abstract}
The European Union (EU) has a splendid record concerning enlargement. Judging by the increasing number of EU member countries, enlargement has been the most successful EU policy ever. The economic side of its eastern enlargement is, however, a hybrid bag of effects for the EU's eastern countries because membership in the EU is not a tide that lifts all boats. This article, as a statistical primer, provides consistent data for the period 2000 2012. Majority of data is from Eurostat, where the data on eastern EU member countries are scattered around in various parts of Eurostat database. In the effort to present the data in a consolidated and straightfoward way to reveal the real economic effects on enlargement on the new EU member countries, we took the task
\end{abstract}

\footnotetext{
* Corresponding Author: Miroslav Jovanović; Global Studies Institute, University of Geneva, 20, rue de l'Ecole de Médecine, 1205 Geneva, Switzerland; E-mail: miroslav.jovanovic@unige.ch.

Co-Author: Jelena Damnjanović; Novi Sad School of Business, Vladimira Perića Valtera 4, 21000 Novi Sad, Serbia (e-mail) jelenaschoolofbusiness@gmail.com.
} 
to cherry-pick the relevant data. It shows that economic growth, expansion of trade, and increase in foreign direct investment to the east of the EU are obvious gains for the new eastern EU countries. That said, it entails costs. The size of domestic and foreign debts have been accelerated to finance their successes. Our concern is that this debt burden stands a chance of suffocating the newly acquired economic vigour especially at a time when one is anxious about the future of the eurozone and the EU.

JEL Classifications: F13, F15, F50

Key words: Enlargement, Old and New EU Countries, Debt, Mixed Blessing

\section{Introduction}

The European Union (EU) has a splendid record concerning enlargement. One may even argue, judging by the increasing number of EU member countries, that enlargement has been the most successful EU policy since the establishment of the European Economic Community (EEC) in 1957. European values such as democracy, the rule of law, market economy, social development and respect for individual, property, and the environment have spread far and wide across Europe and beyond. The EU rewards applicant countries with full membership for achieving successful economic and political reform, but that must be according to the EU's liking. This is an attractive, effective and strong soft power wielded by the EU.

The EU accepted ten new member countries in 2004, mostly from central and eastern Europe. ${ }^{1}$ Bulgaria and Romania both joined in 2007, while Croatia became a full EU member in 2013. Even though the official EU enlargement fatigue exists that is linked to concerns about immigration into the old EU countries and the financial cost of enlargement, the EU has been pursuing its enlargement path. However, from now on, the EU enlargement process will have a glacial pace and face much tougher conditions.

Montenegro, Serbia and Turkey are negotiating full entry conditions, while the Former Yugoslav Republic of Macedonia is an eternal candidate that has been waiting to start entry negotiations since 2005. Albania, Bosnia and Herzegovina are in the

${ }^{1}$ Cyprus, Czech Republic, Estonia, Hungary, Latvia, Lithuania, Malta, Poland, Slovakia and Slovenia. 
waiting room on the way to becoming EU candidates, while Kosovo ${ }^{2}$ is still in limbo. Iceland, a developed and democratic country, turned its back on entry negotiations with the EU in 2013, while Armenia also gave up on the EU in 2013. Armenia received a more attractive economic integration offer from Russia than the EU could propose.

As for Ukraine, the EU offer was a rather non-committal treaty: the opening up of the Ukrainian market for EU-manufactured goods where EU has an edge. Ukraine will have to undergo sustained and extensive restructuring to match the EU's sophistication. The EU's stick came in the form of competition which would increase unemployment in the already troubled Ukrainian economy, while providing no compensation for the restructuring pain of 140 billion euro over ten years and prohibits free movement of people. This EU's stick was balanced against the Russian carrot consisting of 15 billion US dollar in unconditional cash and a reduced price for energy just before the start of the winter in 2013 2014. ${ }^{3}$ When the Ukrainian president opted for the Russian offer, riots ensued, especially in the western and pro-EU part of Ukraine, placing the country on the verge of splitting in two in early 2014. A coup followed.

After the dramatic change of government in Ukraine, the EU unilaterally introduced the temporary removal of customs duties on Ukrainian exports to the EU. The Russian financial offer was withdrawn and the EU promised a matching financial package of 11 billion euro. However, the EU offer 'was conditional of Ukraine signing an agreement with the International Monetary Fund (IMF)' ${ }^{4}$ When the IMF is involved in the running of a country, the neoclassical austerity economic programme is the leitmotif. The IMF's principal clients in Latin America got rid of the organisation's involvement and its economic model. The same happened in Hungary, which kicked the IMF out in 2013.

\footnotetext{
${ }^{2}$ Kosovo under UN Security Council Resolution 1244.

${ }^{3}$ On the one hand, the EU offered substantial loans to Ukraine but through the International Monetary Fund on strict conditions, which included a sharp increase in the price of energy for consumers. On the other, Russian side, Ukraine would pay Russia $\$ 268$ per 1,000 cubic meters of gas (instead of the market price of $\$ 400$ ). This price offer is approximately half of what Germany pays for the same amount of Russian gas. If Ukraine wants to be in the EU sphere, then it ought to pay as much as the EU countries pay and as quickly as they do. Russian pressure on, or dangled carrot to (depending on one's point of view), Ukraine was strongly condemned by the EU side in December 2013. In short, Russia's behavior was utterly unacceptable for the EU and its member countries. However, at the same time, the EU threat in the form of sanctions on trade if Britain dares to leave the EU is perfectly fine, acceptable and appropriate.

'There are several avenues by which the West can offer aid to Ukraine. However, demands for reform, lengthy procedures to approve aid, the European Union's own economic troubles and required coordination among states limit the European Union and United States' ability to match the financial and economic leverage that Russia has in Ukraine. Hence, to avoid a deeper financial and economic crisis, the new government in Kiev will still have to preserve strong financial and economic ties with Russia' (Stratfor, 'In Ukraine, Western Aid Has Limits', 7 February 2014).

Victoria Nuland, the US Assistant Secretary of State for Europe, stated her contempt for the EU and was blunt regarding the EU's relevance and ability to alter developments in Ukraine. She said: 'F-Europe' (A. Evans-Pritchard, 'Whatever your view on EU migrants, Swiss show sovereignty really matters', The Telegraph, 10 February 2014).

${ }^{4}$ EurActiv, 'EU matches Putin's 11 billion euro financial offer to Ukraine', 6 March 2014.
} 
The austerity measures will inevitably provoke additional nationalistic passions in Ukraine, as it continues to be the case in Greece, Italy, Spain and elsewhere in Europe. In contrast, Russia is waiting for Ukraine to pay 11 billion US dollar in gas debt. It is, thus, arduous for Ukraine, if it accepts EU/IMF involvement. Ukraine has only bad choices.

European Union leaders were furious with Russia when it offered a better economic deal to Armenia and Ukraine and then diverted these countries away from a trade deal with the EU in 2013. 'The EU Council chief Herman van Rompuy has said that he will urge Russian leader Vladimir Putin to stop bullying former Soviet countries at the next EU-Russia summit'. ${ }^{5}$ Russia's offer include access to the huge Russian market, subsidised prices for energy, and cooperation in security matters and immigration. Let it not be forgotten that prosperous Russia is potential homes for tens of millions of migrants from the former Soviet states. It is the prime migration target country after the United States, the EU and the Arab oil producing countries. The EU's offer certainly could provide various economic gains in the long term to Ukraine's uncertain future, but at the same time it could engender a certain and immediate increase in Ukraine's unemployment rate. The EU's empty coffers could not provide the nearly bankrupted Ukraine with outright compensation. ${ }^{6}$ Nonetheless, the preamble of the EU-Ukraine Association Agreement was signed in Brussels on 21 March 2014.

The EU's policy stance on Russia's bullying of Ukraine is somewhat surprising

\footnotetext{
${ }^{5}$ A. Rettman, 'EU to complain to Russia on Ukraine’, EUobserver, 29 November 2013.

${ }^{6}$ Ukraine is a split society and a polarised country on religious, linguistic, economic and historical grounds (something like Serbs and Croats in the former Yugoslavia). The 2014 coup in Ukraine brought to the fore a colourful new Government (certain extreme rightwing groups such as Svoboda took very important posts). The West that marches through the North Atlantic Treaty Organisation's (NATO) enlargements towards post-Soviet Russia tolerates such developments in Ukraine (no matter the cost) as long as the Government is not proRussian. Perhaps little was learned in Afghanistan about the evils that can be created by democratic countries.

'To progressives who have been celebrating the revolution in Ukraine: Be careful what you wish for. Ukraine now has the first European government in decades in which outright fascist parties have gained a significant role in the executive branch. In other European countries, far-right parties have won seats in the parliament, but not secured real power in the cabinet. Of course, not all Ukrainian revolutionaries are fascists or Nazis, as asserted in recent Russian propaganda. But it is equally wrong and irresponsible to assert that the presence of fascists and Nazis in the new government is merely Russian propaganda', (Z. Grossman, 'Ukraine: the enemy of your enemy is not always your friend', Counterpunch, 11 March 2011).

The new 'revolutionary' Parliament in Ukraine repelled the law on bilingualism (Ukrainian and Russian). This was among the sparks that initiated the referendum on the secession of Crimea (majority of Russian speakers) from Ukraine and its joining the Russian Federation (which it subsequently did). The West introduced some light sanctions on Russia (travel bans for some officials). The EU's leaders do not like referendums, especially when they do not get the vote that they like. In the EU, they request as many encores as they wish. In Crimea, that was not possible. There was also no referendum on the absorption of East Germany by Western Germany.

Incidentally, the Soviet leader Nikita Khrushchev (a Ukrainian) gave away the Crimean peninsula from Russia to Ukraine in 1954. This was against the constitution of the Soviet Union but in a dictatorial regime all is possible. Khrushchev did that to win back the hearts and minds of the Ukrainians as he, as the Ukrainian party secretary, was involved in ruthless purges during the times of Stalin.

Russia reacted swiftly to the independence referendum in Crimea. Russia wanted to draw and show the red line to the West. The reason is that if NATO was to come within $400 \mathrm{~km}$ of Moscow, all Russian nuclear arsenals would be useless as there would be no time to react (the same reason why President John Kennedy did not want the Soviet missiles in Cuba). Would perhaps a superior Russian strategy be to let the EU/IMF enter Ukraine, make an economic Chernobyl, and then let the cash-full Russia enter as a saviour?
} 
as it occurred around the same time that the EU threatened (bullied) Britain with trade sanctions if Britain dared to leave the EU. Are these double standards applied in practice?

Many countries that are in the EU waiting room, especially Turkey, may end up with a status akin to that of Norway or Switzerland which have free access to the single European market without full membership.

The EU's great success in enlargement is not absolute. Algeria was an integral part of France at the time of the creation of the EEC (1957). Nonetheless, it seceded from France in 1962 and hence left the European integration club. Greenland, which is a part of Denmark, voted in 1984 on the issue of continued membership in the European Community and decided to leave it in 1985. Britain had a referendum in 1975 on its continued membership in the EEC and decided, at that time, to stay. A new referendum in 2017 will test whether Britain will remain.

Almost a decade has passed since most of the formerly communist eastern European countries joined the EU. This leaves enough time to assess the economic impact of enlargement. The purpose of this article is to consider the economic dimension of eastern enlargement on the new member countries. The shining set of political successes such as strengthening of the rule of law, deepening of democracy and reinforcement of human rights have been left outside of this article. The period of observation starts in 2000 , four years before the time of entry for most of the eastern countries, and ends in 2012, the latest year for which data is available. Following this introduction, we discuss theoretical basics on enlargement of Section II.

Section III presents statistical data and comments on the principal economic indicators. We used data from the same source, Eurostat. Eurostat is a huge institution which publishes an enormous quantity of data. The data on eastern EU member countries are scattered around in various parts of Eurostat database. We took the task to cherry-pick the relevant data. Once the data are put together, we are finally ready to take a look at the statistics from the new EU member countries in one place. Making these efforts, we present the data in a consolidated and straightforward way to reveal the real economic effects of enlargement on the new EU member countries, and thus exposing the myth of the EU's economic rose garden.

The exposing EU membership was expected to be generally favourable in the past for the acceding countries. Data in this article show that this was not always the case for the countries in central and eastern Europe. A number of their expectations were not fulfilled. Section IV highlights the mixed bag of economic effects experienced by the 
eastern countries upon their EU entry with concluding remarks. The eastern countries have been living on a 'credit card' from future generations.

\section{Enlargement: a theoretical note}

One may argue that international economic integration offers attractive benefits such as an enlarged and secure market, elimination of tariffs and non-tariff barriers on various manufactured goods that meet the stipulated rules of origin, while the use of other barriers may be seriously restricted, the ability to include services and agricultural goods in the deal, the possibility to liberalise and secure FDI, labour mobility may be permitted among integrated countries. There is also a possibility of having a cosy and efficient dispute settlement system within the group. It might not be realistic to expect the achievement of such objectives through multilateral negotiations in the short term. Hence, integration on a regional scale may be faster in achieving these goals, especially when there is a new bottom-up wave of integration through a network of supply chains as is the case in Southeast Asia.

Suppose that compensatory payments between 'integrated' countries are allowed. In this case, any customs union or preferential trading area is potentially favourable to all countries that consider participation, since they can be compensated for eventual losses incurred in the integration process. This means that the customs union among countries can be extended to $n+1$ countries. This also implies that there is an incentive to extend the customs union until the whole world is included, until free trade prevails across the world. Preferential trade blocs can be constructed in a way that the welfare of the outside countries is unaffected (Kemp and Wan, 1976). For example, a deeper integration within the EU caused wider integration in Europe. A market deepening, The Single Market Programme (1985 1992), triggered membership requests from Austria, Finland and Sweden that were previously happy to be outside of the EU. Once a group enlarges, the cost to non-members of staying outside of the club may increase. Hence, there is a domino effect regarding applications to integrate (Baldwin 1995, p 46). If there are no entry costs and no strong political objections, this process may, in theory, lead to universal free trade and may be a building block towards multilateral liberalization in trade and investment. Lipsey and Smith (2011, p 117) argued along those lines that: 
'...the more that countries have Regional Trade Agreements(RTAs) with their major trading partners, the less they have to worry about negative effects from Multilateral Trade Agreements(MTAs) and the more they have to gain from removing the administrative costs associated with Rule of Origin(ROO) in multiple overlapping RTAs. Thus, over the long term, the proliferation of RTAs that seems so messy in the short term, could be the only realistic road to really embracing MTAs.

Finally, we suggest that because the current wave of RTAs is embedded within a robust trading framework in the World Trade Organization(WTO), there are grounds for optimism that the process of competitive liberalisation in RTAs will lead eventually to further multilateral liberalisation. ${ }^{7}$

Interest in joining a customs union or any other type of preferential trade may exist even without compensatory payments ('bribes'). In fact, such compensation is hardly ever paid in practice. The reason for this is simple. The larger the integrated bloc, the greater the internal trade. Consequently, there is a greater possibility that the group may affect terms of trade with the third countries to their favour. If other things remain unchanged, the countries that are left outside the group may lose over time. Therefore, every new country that joins the integrated group creates additional push motives, typically called as a snowball effect, for other countries to join. Outside countries may face shrinking markets, leading their competitive domestic producers to lobby to join the integration group. In theory, the group could enlarge until it covers the whole world.

Countries like to be a member of a select club. The monkey see, monkey do factor plays a role. Alan Winters put this succinctly by comparing preferential trade deals to street gangs, "you may not like them, but if they are in your neighbourhood, it is safer to be in one" (Mansfield and Reinhardt 2003, p 857).

While Viner (1950) questioned the overall welfare effects of the creation of a customs union, Kemp-Wan and Lipsey-Smith seem to bring back the pre-Viner perception that customs unions are always welfare improving devices in the long term. The Kemp-Wan smooth scenario, perhaps one of the most elegant pieces of reasoning in international economics, is often interpreted in a way that relates to two postintegration elements: (i) the level of tariffs; (ii) the volume of trade with outsiders.

If tariffs are lowered while trade and investment with outsiders increase, integration is globally beneficial. That said, if one wants to get a fuller picture of the welfare

RTA - Regional Trading Agreement; MTA - Multilateral Trading Agreement; ROO - Rules Of Origin. 
effects, one must consider changes in the terms of trade between the customs union and non-members countries.

The general Kemp-Wan argument hinges on the supposition that the integrated countries are open and that they welcome new entrants. The possibility of either blocking any new enlargement or making the entry costs excessive without full compensation, puts this neat scenario into question.

The more countries there are in a customs union, the greater the potential demand and need for compensation will be. If certain adjustment schemes are adopted in reality, they are often the products of skillful bargaining and political circumstances, not purely the outcome of the economic impact of integration. The experience of the EU, its creation and enlargements, illustrates this point well. Political considerations very often play a major role in integration and the expansion of the group. The accession of Greece to the EU in 1980 is a prime example to support this observation. The same holds for the entire eastern enlargement of the EU.

\section{Economic Effects}

Let us start first with basic data on GDP in the new eastern member countries (Table 1). A striking feature is that all of these countries demonstrated economic growth both before and after EU entry. Another issue is that the rates of growth in the new EU countries before the financial crises in 2007 2009, were significantly higher than the average growth rates in the old EU countries. This is, of course, the consequence of their lower starting point, but the fact still remains that these countries were expanding fast. The crises hit hard in the east, hence the fall in GDP in 2009 was, on average, deeper in this group than in the western members of the EU.

Table 2 presents GDP data per capita in euros. There is an obvious gap among new and old members of the EU. An encouraging fact is that most of the eastern countries almost doubled their GDP per capita in the period 2000 2012. Still, there is a huge gap between the average EU GDP per capita and the same indicator in most of the eastern EU member countries. Nonetheless, the growth of per capita income (Table 3) has been faster than the EU average, except for the crisis years. Manufacturing production experienced a constant rise from the year 2000 (Table 4). However, the crisis year 2009, was especially noticeable for the entire EU. 
Common Agricultural Policy (CAP) has been the most prominent EU economic policy together with trade, competition and enlargement. The new member countries expected a fair share of the CAP benefits, i.e, generous subsidies. In fact, the EU's eastern countries have on average, a much higher reliance on agriculture than the western members of the EU, where the contribution of agriculture is only about 3 per cent of GDP. Gross value added in agriculture in the eastern EU countries increased (Table 5), but labour input was on a constant decline (Table 6). The hope that the opportunities to export food westwards would improve employment in farming was not materialize. Cattle production may join various streams of agricultural production, such as land, corn, milk and meat, and also it indicates the living standards of the population because the higher the income, the higher the consumption of meat is expected. Table 7 offers data on the cattle population in the region. The cattle population either declined or in the best case, remained unchanged. This is surprising as income increased in the east. Still, the eastern farmers were not able to compete with the very productive and highly subsidised farmers in the old members of the EU. So, a slight decline in the total cattle population in the EU is observed. Farmers in eastern EU countries will be entitled to receive full EU farm subsidies by 2020. This is almost a generation after their EU entry. In general, there has been a huge discrepancy in the east regarding what these countries expected from the EU in farming and what they actually received once they joined the EU.

Income in agriculture either fell in the period 2000 2012 or remained unchanged. The exceptions are Latvia and Lithuania, where there was certain increase (Table 8).

Many eastern countries started the period with a rather high rate of unemployment (Table 9). In spite of obvious emigration towards the old EU countries, EU entry did not bring about a clear and noticeable change in the rate of unemployment. In general, a similar finding may be observed for labour productivity (Table 10).

After the EU entry in 2007, Romanians flocked to Spain among other countries. The old 15 EU countries may not impose restrictions on labour mobility, but they were able to do so for the new members from the east for a period of seven years after their EU entry. For Bulgaria and Romania, the expiry date of this limitation was 2014. Spain decided to lift this restriction in 2009 and more than 800,000 Romanians migrated to Spain where the language similarity played a certain role. They outnumber Moroccans, Ecuadorians and almost Britons living in Spain. The booming construction business in Spain brought strong demand for their labor services. However, the recession had a negative impact on the construction of new dwellings and shopping centres and thus 
about 30 per cent of Romanians living in Spain were unemployed in 2011. Under EU rules, the unemployed are eligible to receive the same unemployment benefits as local people. The economic situation was so harsh that Spain re-imposed barriers to the inflow of new migrants from Romania in 2011. The European Commission approved such a temporary measure until the end of $2012 .^{8}$

Over 3 million Romanians ${ }^{9}$ and over 1.5 million Poles live abroad. Smaller countries such as Lithuania and Bulgaria are the most depopulated in the EU. Bulgaria has 7.3 million inhabitants and the country has lost 1.5 million people since 1985 . This is a high depopulation record not just for the EU, but also by global standards. ${ }^{10}$ Even though the eastern EU countries may be suffering from depopulation, these people still live in the EU. Such developments are similar to what happened during the 1980s when Spain and Portugal joined the EU.

The rate of inflation during the period 2000 2012 was largely under control throughout the region (Table 11). This rate had a slight deceleration tendency which shows that the monetary authorities were able to handle it.

The budget deficit indicator is presented in Table 12. Apart from 2009 as an exceptional year, most of the eastern EU members were very close to the Maastricht Treaty's prescribed fiscal deficit maximum of 3 per cent of GDP. In fact, the eastern countries that were outside of the eurozone were following the eurozone's basic rules better than the full eurozone members. The same is true for the government debt level prescribed by the eurozone, 60 per cent of GDP (Table 13). The eastern non-eurozone countries exhibited an excellent performance regarding this indicator. However, the troubling sign is that while the average eurozone government debt increased from 70 per cent in 2004 to 91 per cent in 2012, the same debt in the eastern EU countries usually doubled if not tripled. Bulgaria is an exception as its debt remained largely undisturbed in the period 2007 2012.

Tables 14 and 15, respectively, confirm that trade was an engine of growth for the new EU member countries in the east. There was a strong and continuous expansion of

\footnotetext{
${ }^{8}$ S. Pignal, 'Spain to curb flow of Romanian workers', Financial Times, 11 August 2011.

${ }^{9}$ 'Of Romania's 7 million strong active labour force, around 1.1 million have a secure job in the state sector, which they will hesitate to give up. Some 3 million have already left in the wake of Romania joining the EU in 2007: about 1 million went to Italy, another million to Spain, half a million to France, up to 400,000 to Germany and 120,000 to Britain. They worked in a 'self-employed'capacity (40 per cent of the workforce building London's Olympic Stadium were self-employed Romanians) or as seasonal or low-skill workers. Some were exploited, as they did not have the same legal protection as nationals; others didn't pay tax' (The Economist, 'The gates are open', 4 January 2014.)

${ }^{10}$ EurActiv, 'Expert: Nothing wrong with EU population shifts', 2 September 2011.

${ }^{11}$ The absolute volume of the gross foreign debt and its exploding dynamics is presented in Table 20.
} 
exports and imports following EU entry. This reconfirms the expectation that European integration increases trade. However, apart from Estonia, Latvia and Malta, all eastern countries had a deficit in trade (Table 16).

Integration and EU entry also stimulated inflow of FDI in the east of the EU (Table 17). The biggest beneficiary of FDI inflows was Poland where the size of the domestic market also played a role in the attraction of FDI. Even though these countries were net beneficiaries of FDI, they were also a source of FDI (Table 18). One may note an exodus of FDI from Hungary, especially after 2010. Some investors were leaving for China.

Our final set of tables is devoted to foreign debt (Tables 19, 20 and 21, respectively). In general, the foreign debt of the eastern EU countries almost doubled vis-à-vis GDP since their EU entry. The current economic success is heavily financed by people borrowing from their children and grandchildren. This phenomenon is referred to as inter-generational transfer where those that are supposed to foot the bill in the future are not asked for anything now. The exception is Bulgaria, which kept the same level of foreign debt. Certain indebted countries such as Hungary had to call the IMF for a rescue, but after the IMF imposed harsh austerity policies, Hungary decided to rescind all assistance from the institution and closed the IMF's office in 2013. One may observe a decrease in Hungary's debt burden in 2011 and 2012 in Table 21. The troubling sign is that the indebted eastern economies may not have access to the capital market with favourable terms. Belt tightening would be necessary, but it will have a negative impact on employment, trade, and especially on growth in the future. If there are moves towards a more federal structure of the EU, including the banking union and direct federal transfers of resources to the disadvantaged countries, a number of eastern EU member countries will be beneficiaries. If one compares debt and GDP growth rates (Table 21), one may conclude that debt acceleration is much faster than the rate of GDP growth. Hence, these countries, just like the rest of the world, were living on a credit card.

\section{Conclusion}

When full integration of central and east European countries in the EU was first discussed at the beginning of the 1990s and when it was merely a remote possibility, 
everyone was enthusiastic about the idea of enlargement. As the date of entry approached, this enthusiasm evaporated and serious doubts emerged. Some say that the EU carried out a promise that many now wish had never been made, at least not so quickly. The general mood was anxiety rather than celebration. The leaders in the old EU countries failed to explain to their citizens the overall benefits of the eastern enlargement. The eurozone crisis created a sharp north-south division within the EU. 'Croats watching the EU's stumbling attempts to contain the eurozone crisis wonder if they are joining "just in time for the funeral". Hence, many in the EU question its continued (economic) attraction. A single vision and idea about the EU's future path does not exist. To some, the EU may no longer be the fuel from which one can get significant political mileage. Others rejoice: the eastern enlargement of the EU is a very good thing as it marks the end of the east-west divide in Europe. Nonetheless, the EU continues to be a global beacon of democracy, rule of law and a leader in the protection of the environment in a troubled world.

The economic side of EU enlargement is a mixed bag of effects for the EU's eastern countries. Membership in the EU is not a tide that lifts all boats. This article (it may be regarded as a statistical primer) provided data which show that economic growth, expansion of trade and increase in FDI to the EU's east are obvious successes and gains for the 'new' EU countries. The EU's eastern countries are fusing with the rest of the 'old' EU. Eastern economies are modernising, but there is a cost: it has been a fast acceleration in government and foreign debt that has financed those successes. The danger is that this debt burden may partly suffocate economic vigour, enthusiasm and initial optimism in the eastern part of the EU. The former communist EU countries have been living on a 'credit card' debt that will have to be settled by future generations.

Uncertainty about the eurozone's future; no prospects for any significant growth in the eurozone for many years to come; the division between the EU's north and south; intermittent riots in the south of the EU; the possibility that some countries may leave the EU; and apprehension about migration within and into the EU, have all ensured that the general mood in the EU will be sombre for the coming decade.

Received 2 January 2014, Revised 20 March 2014, Accepted 24 March 2014 


\section{References}

Baldwin, R. (1995), “A domino theory of regionalism' in Expanding Membership of the European Union (eds R. Baldwin, P. Haaparanta and J. Kiander)", Cambridge: Cambridge University Press, p. 25-48.

Kemp, M. and H. Wan (1976), "An elementary proposal concerning the formation of customs unions", Journal of International Economics, p. 95-97.

Jovanović, M. (2013), The Economics of European Integration. Cheltenham: Edward Elgar.

Jovanović, M. (2013), "Was European integration nice while it lasted", Journal of Economic Integration, p. 1-36.

Lipsey, R.G., and M. Smith (2011), "Multilateral versus regional trading arrangements: substitutes or complements?”, in (ed. M. Jovanović) International Handbook on the Economics of Integration: General Issues and Regional Groups. Cheltenham: Edward Elgar, p. 90-120.

Mansfield, E. and E. Reinhardt (2003), "Multilateral determinants of regionalism: the effects of GATT/WTO on the formation of preferential trading arrangements", International Organisation, p. 829-862.

Viner, J. (1950), The Customs Union Issue. London: Stevens and Sons. 


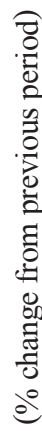

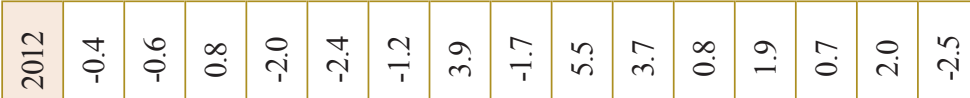

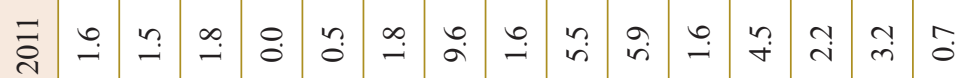

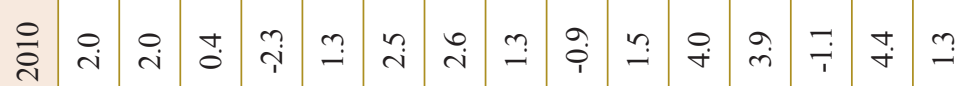

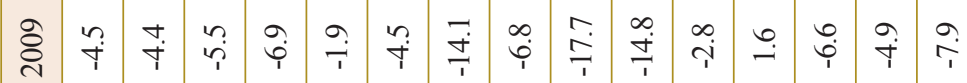

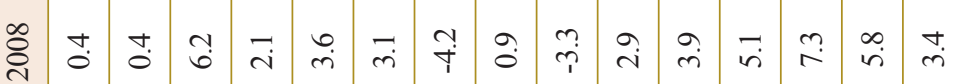

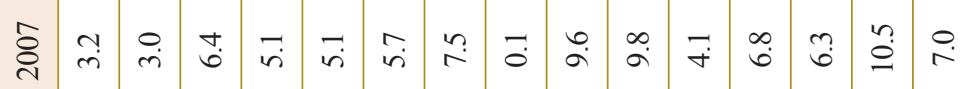

ஓ̆丶

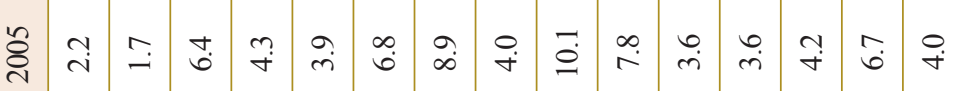

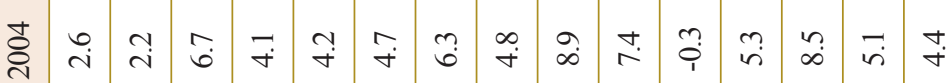

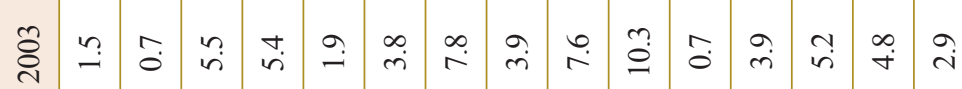

§ิ઼

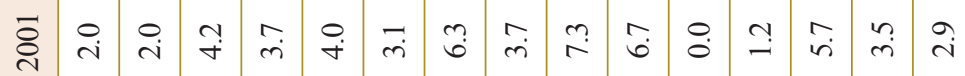

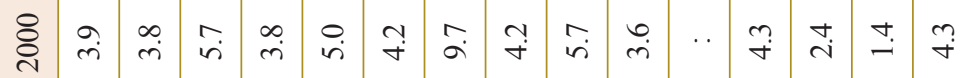




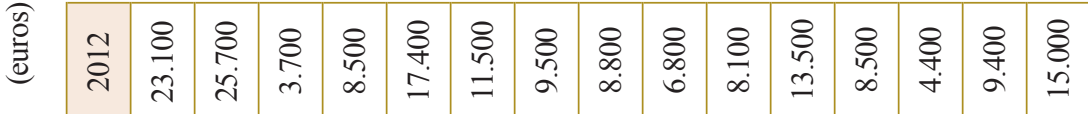

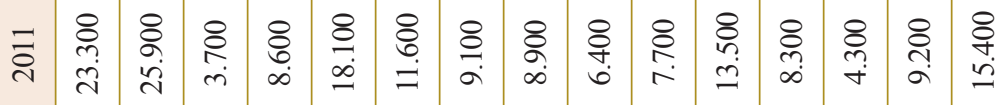

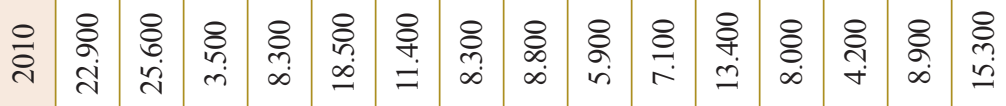

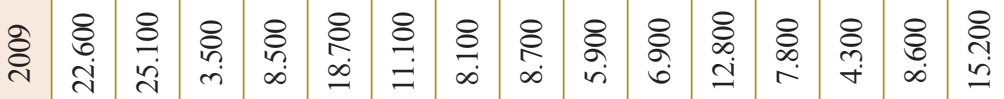

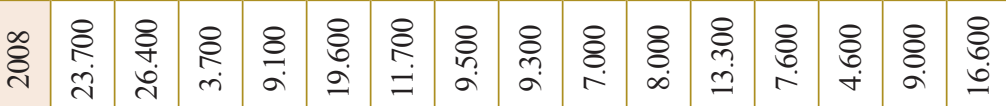

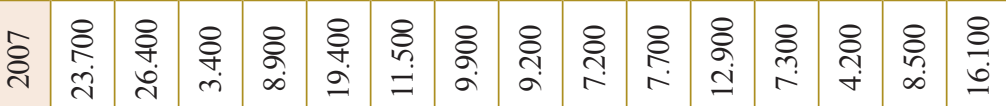

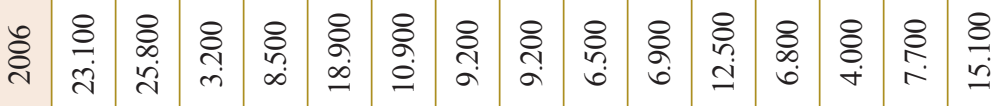

ฮี้.

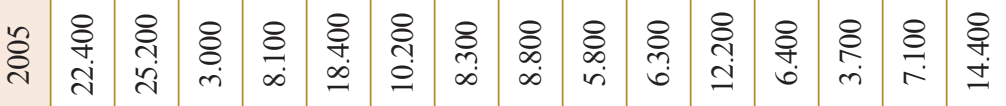

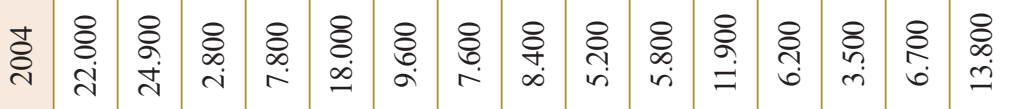
\&

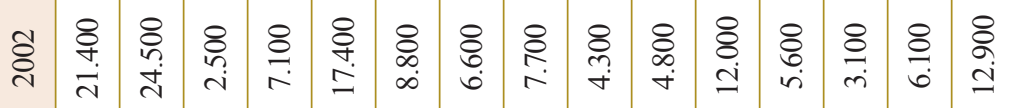

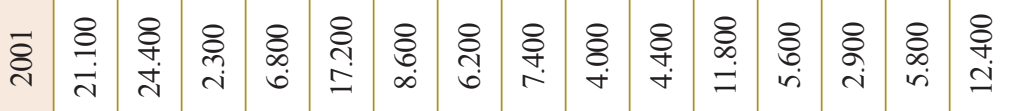

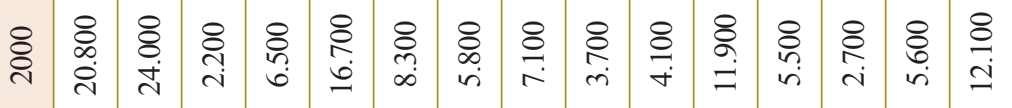

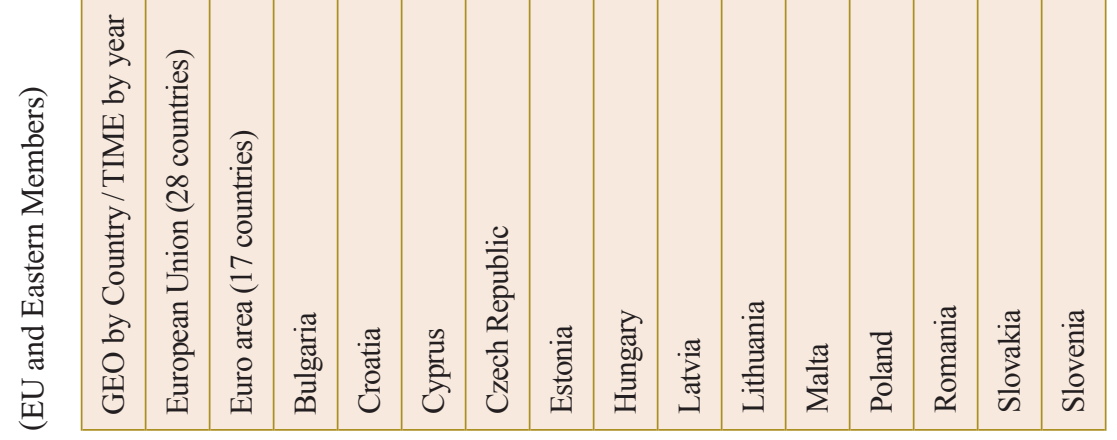




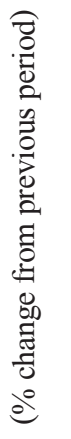

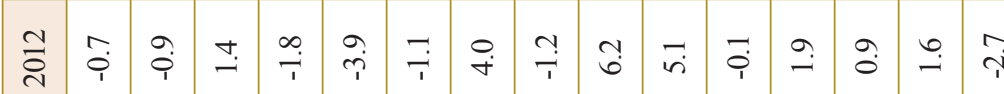

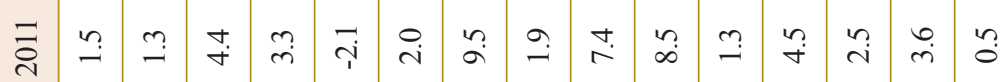

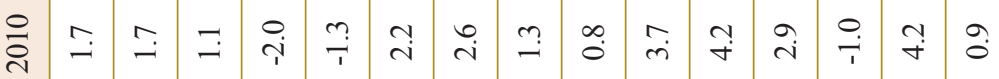

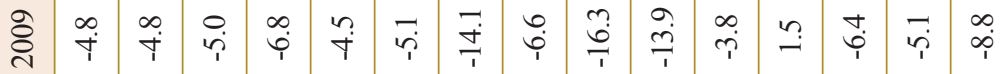

离

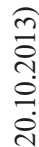

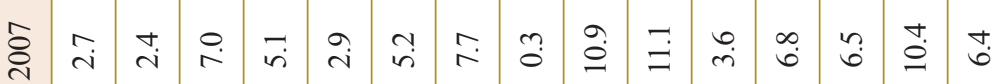

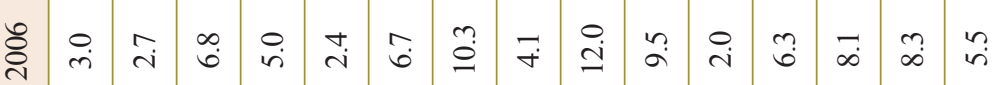

हैं

\begin{tabular}{|c|c|c|c|c|c|c|c|c|c|c|c|c|c|}
\hline$\cong$ & $\exists$ & $\hat{\jmath}$ & $\stackrel{m}{f}$ & 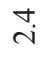 & & $\vec{a}$ & $\stackrel{\sim}{\sim}$ & $\stackrel{m}{=}$ & $\stackrel{\circ}{\circ}$ & $\stackrel{\circ}{\dot{m}}$ & $\hat{m}$ & $\stackrel{ナ}{+}$ & $\ddot{b}_{0}^{\circ}$ \\
\hline
\end{tabular}

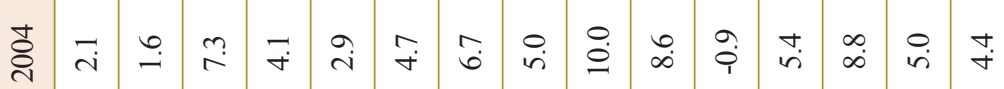

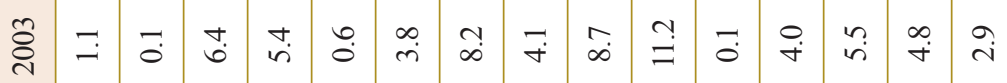

§ิ

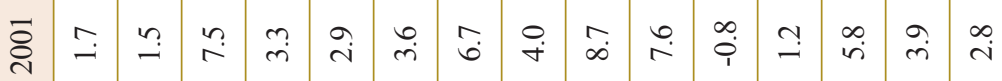

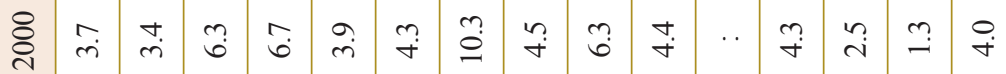

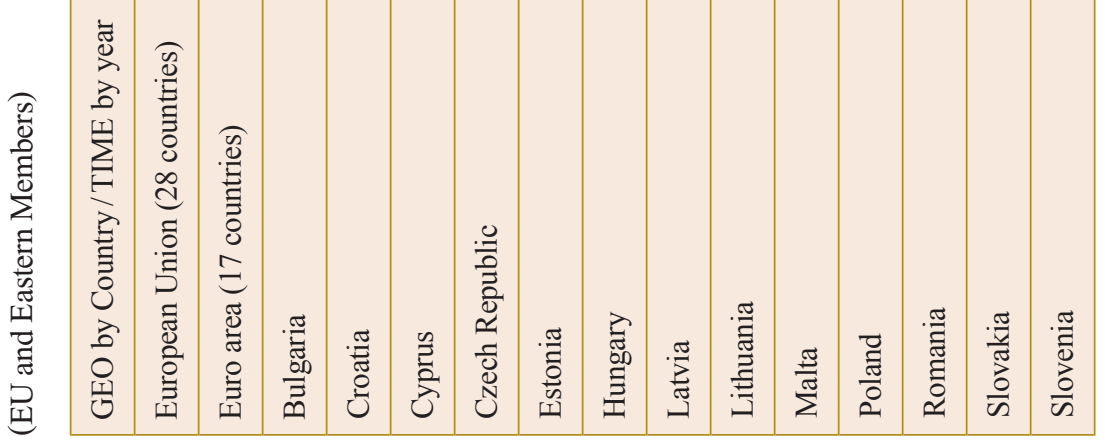




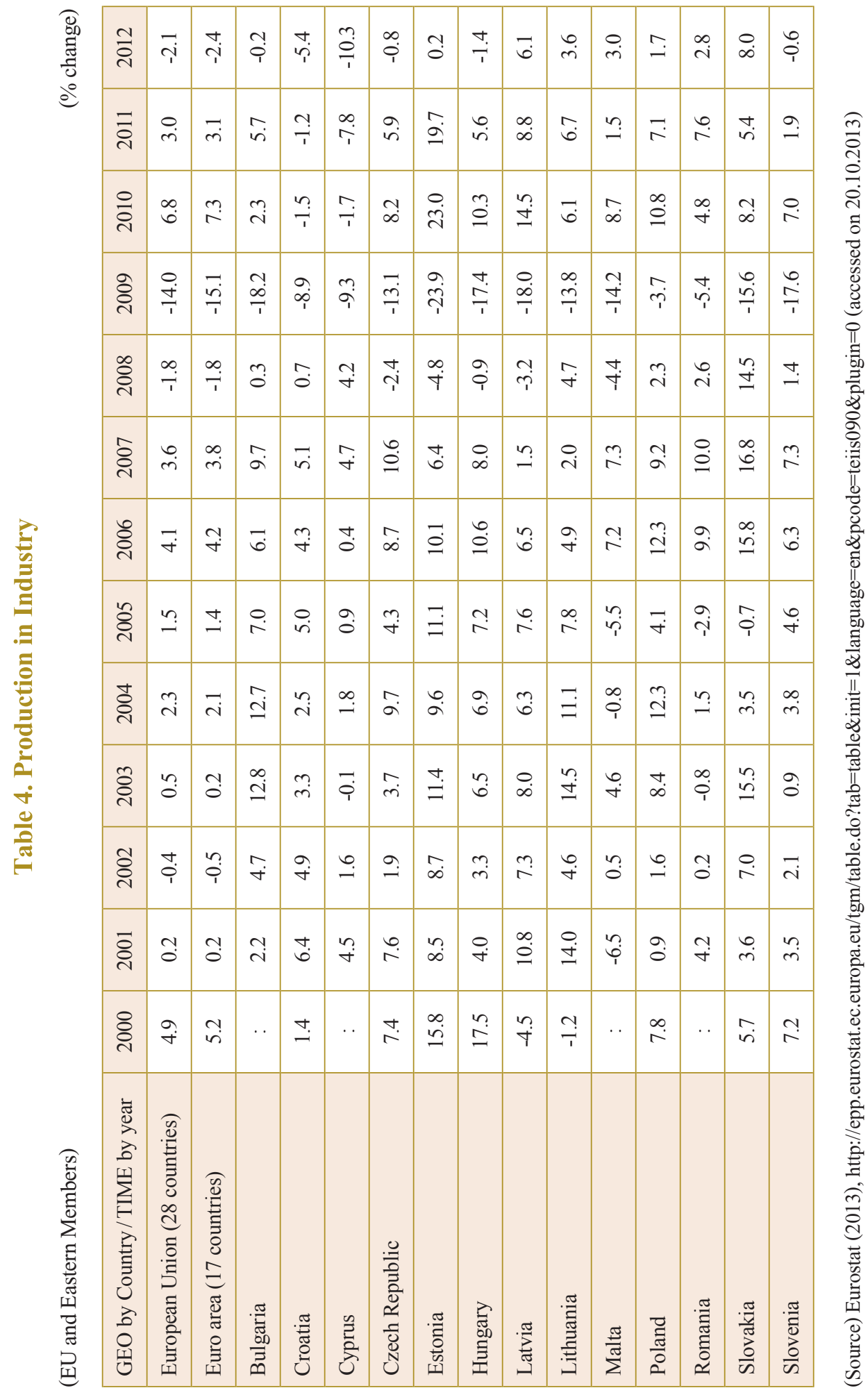




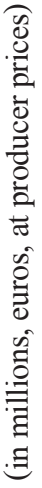

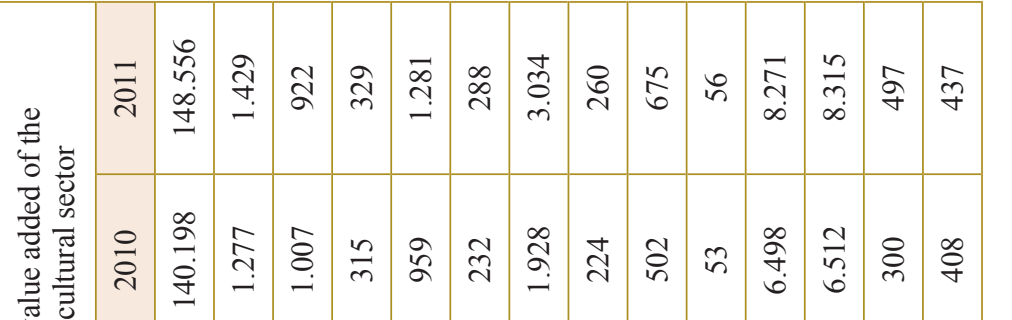

ลิ

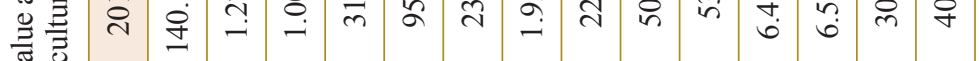

ธ่

क 50

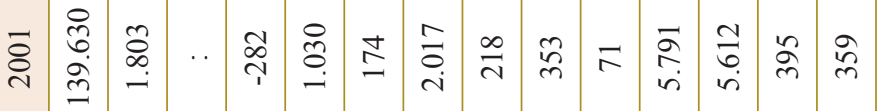

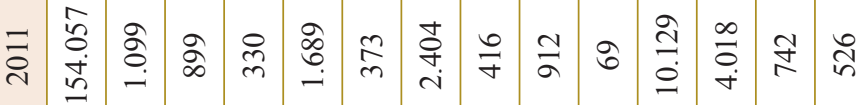

言

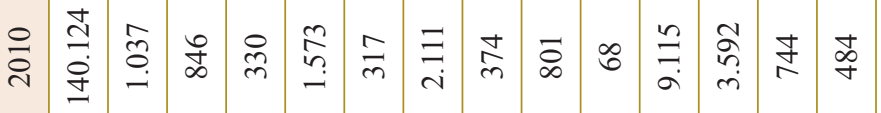

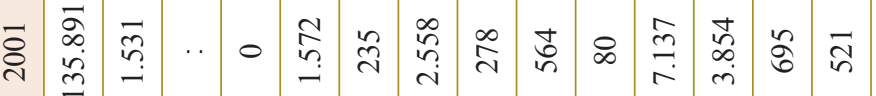

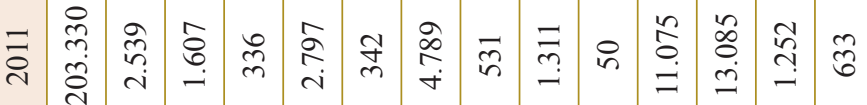

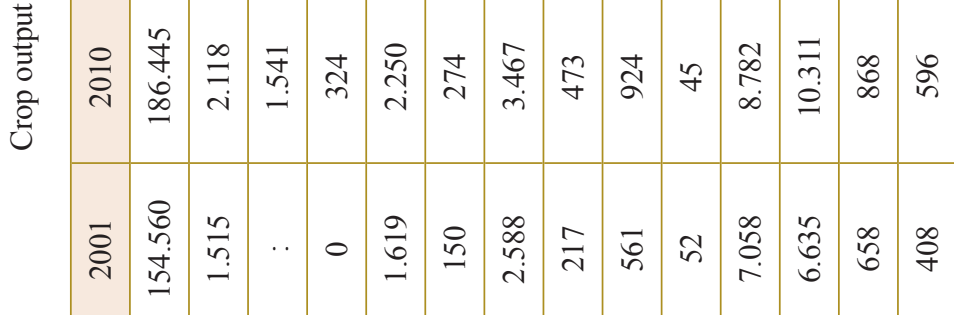

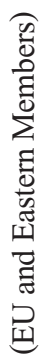

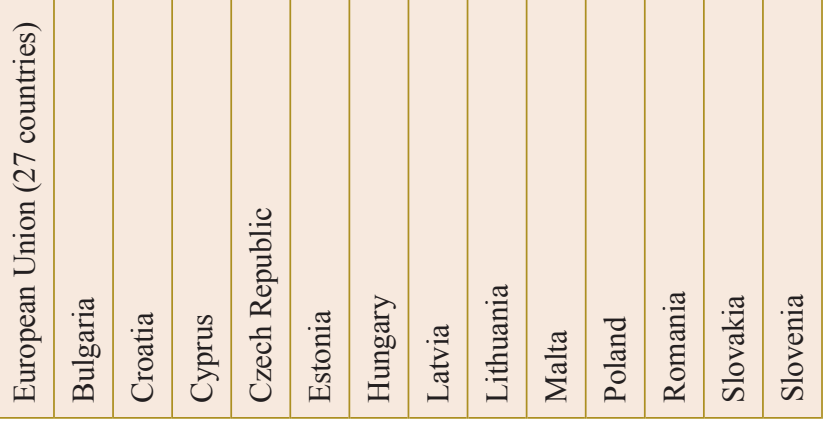




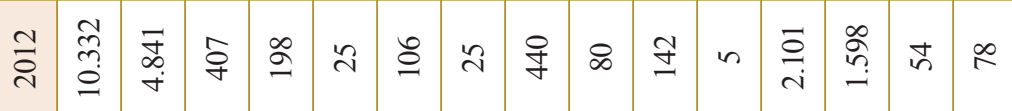

స

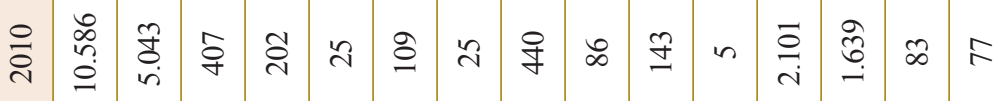

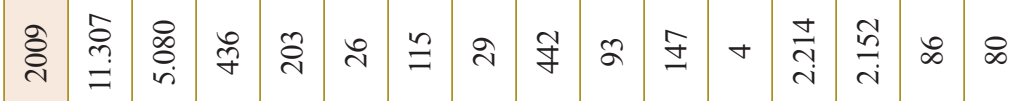

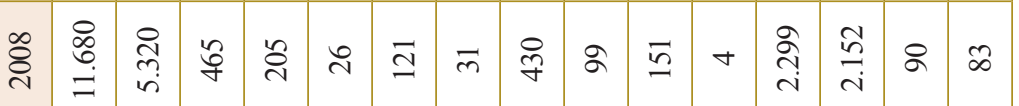

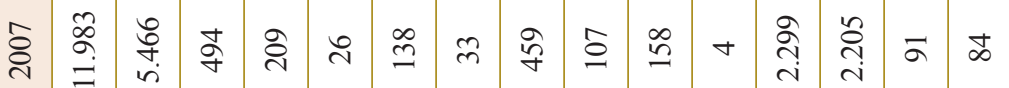

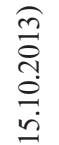



¿্خ

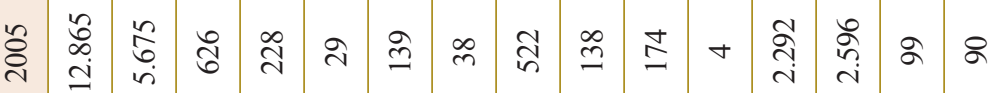

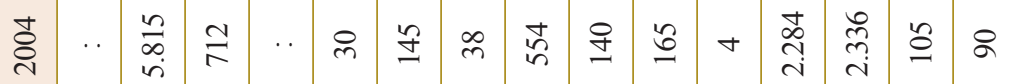

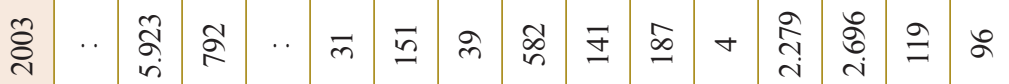

రి

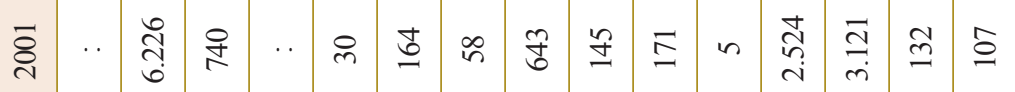

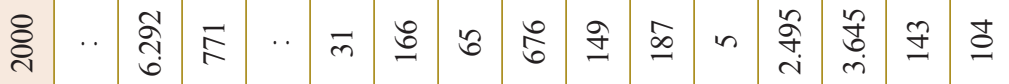

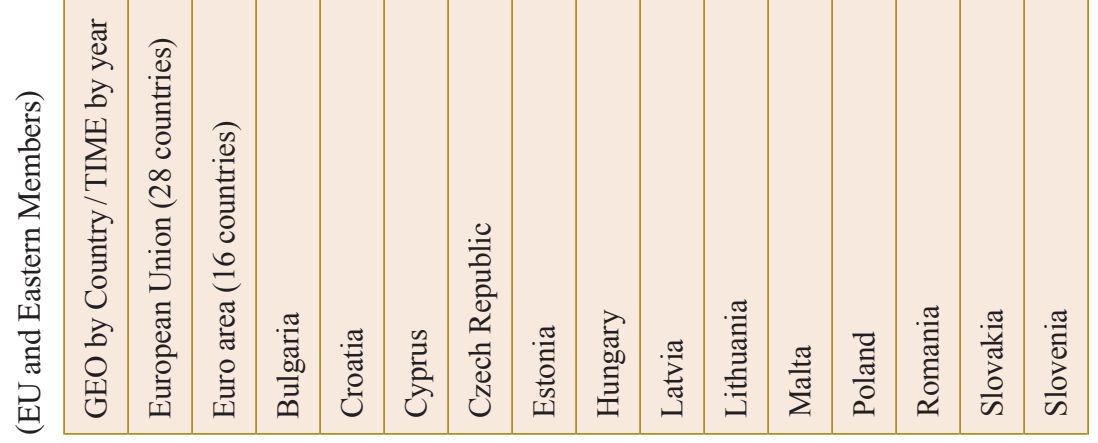




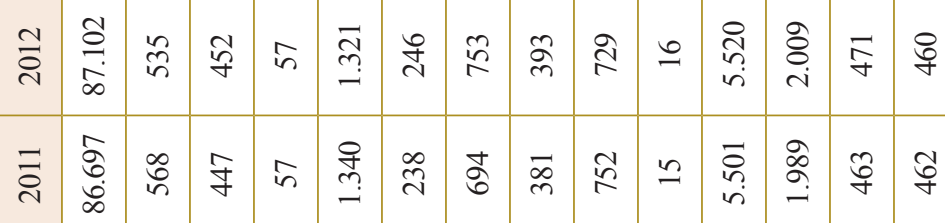

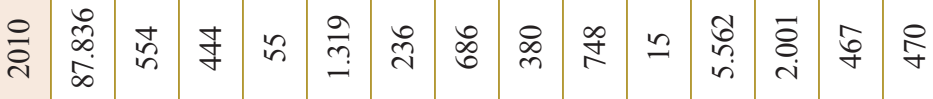

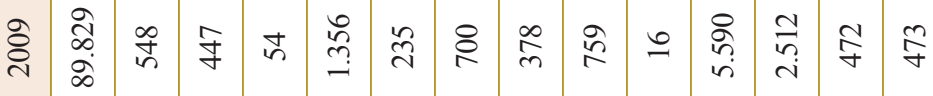

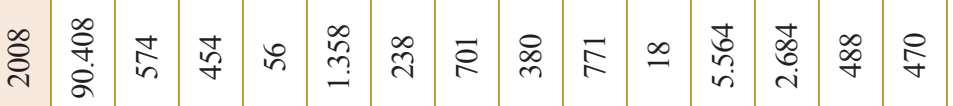

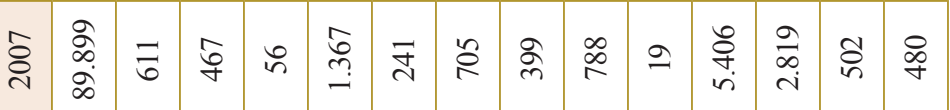

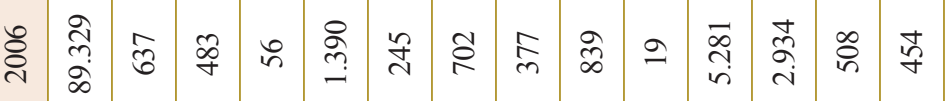

உี

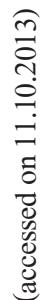

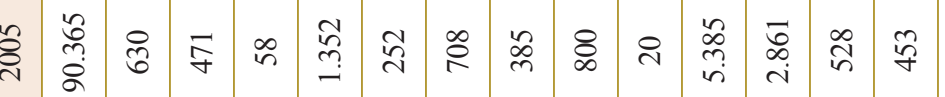

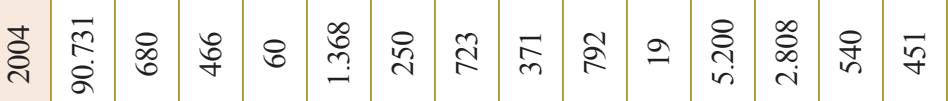

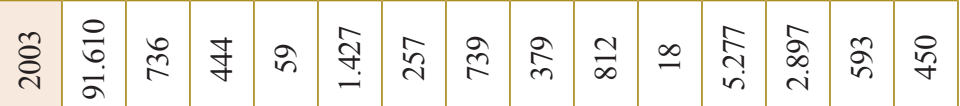

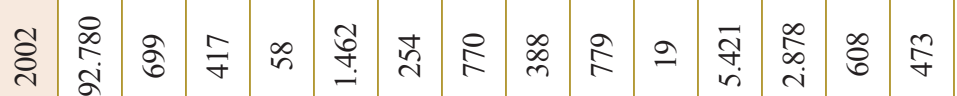

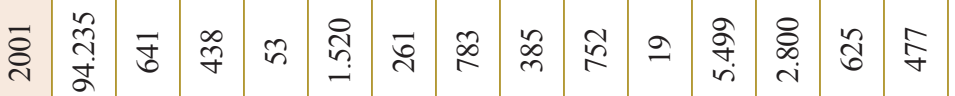

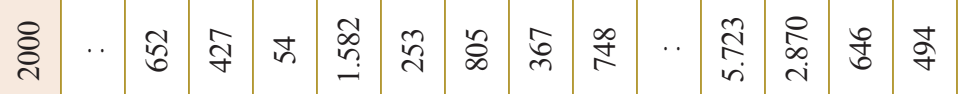

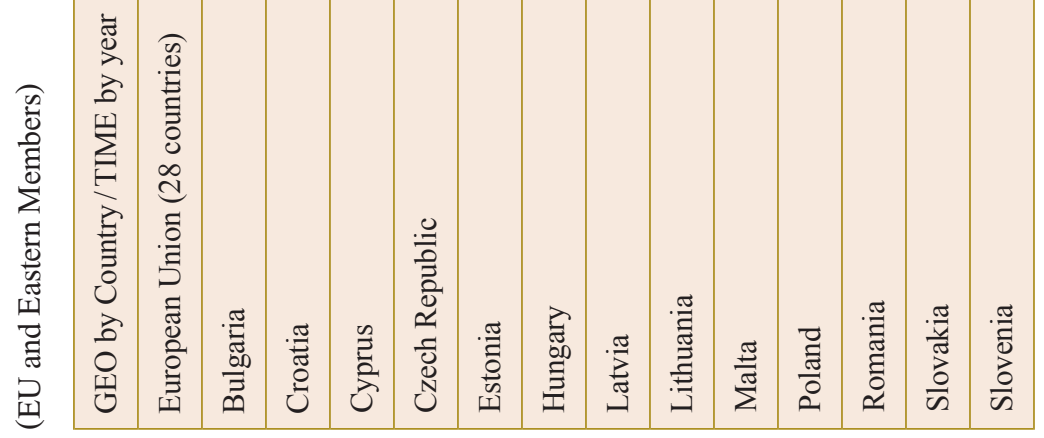


80
.0
0
0
0
.0
0
0
0
0
0
0
0
$\frac{\pi}{0}$
0
0



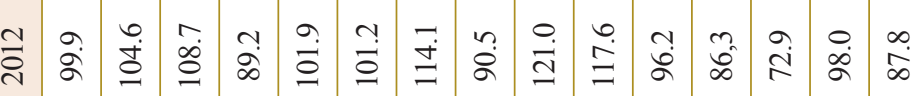

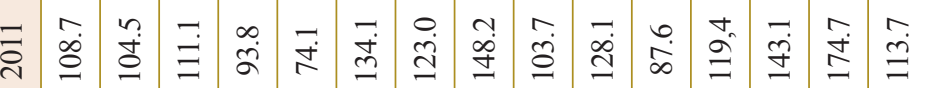

윰

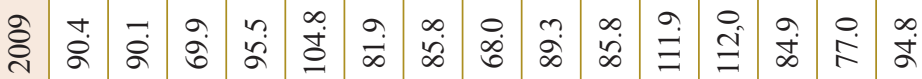

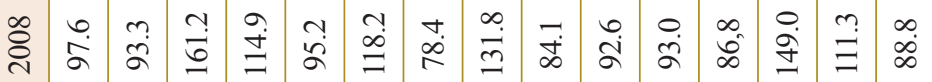

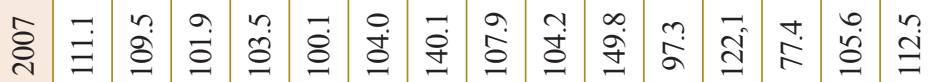

\&̊ํ)

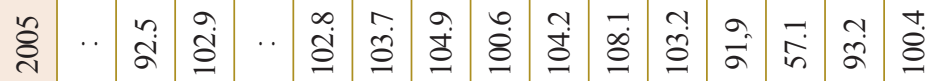

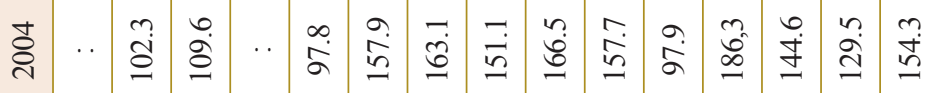

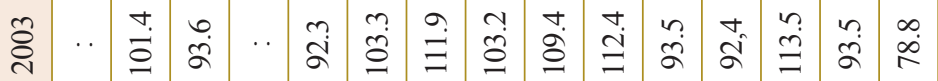

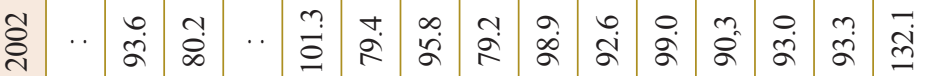

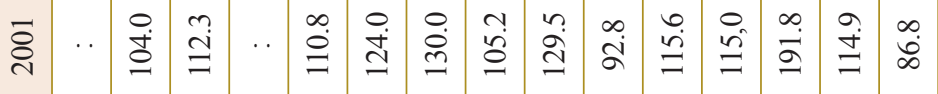

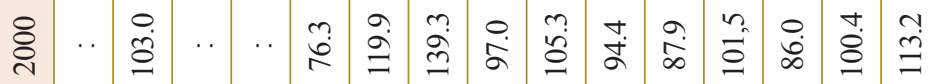

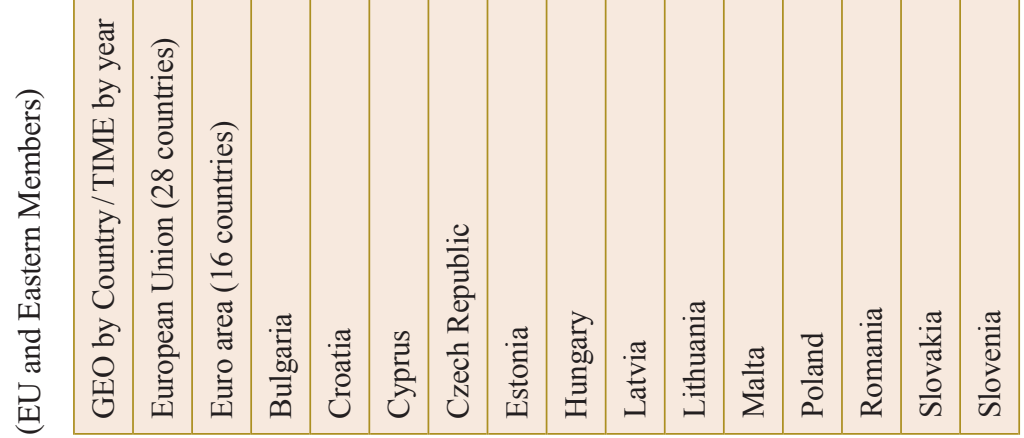

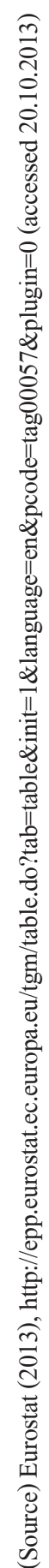




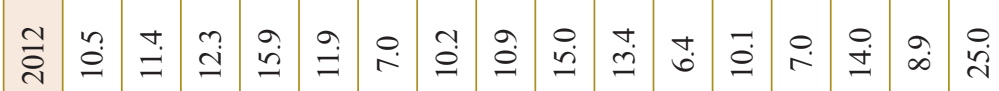

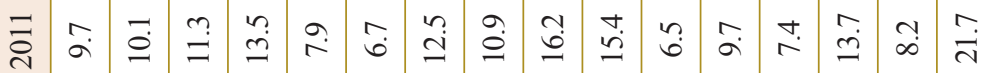

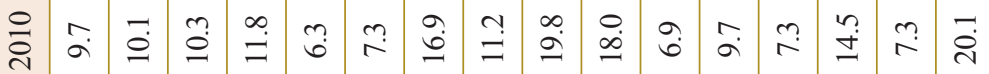

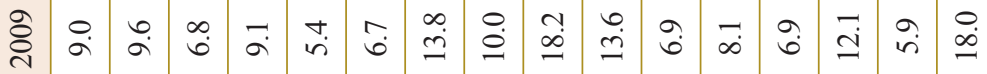

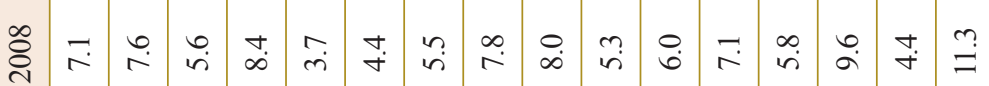

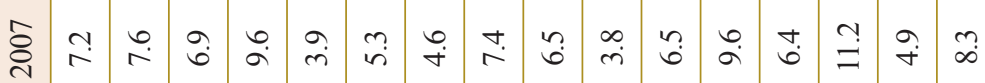

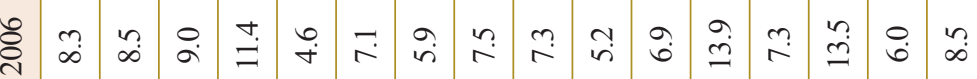

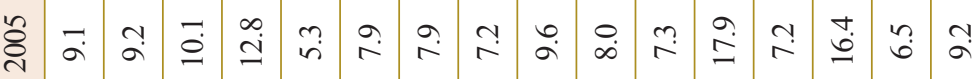

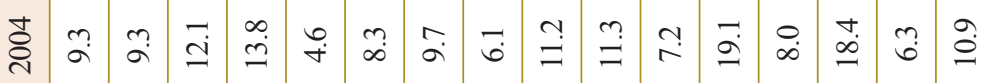

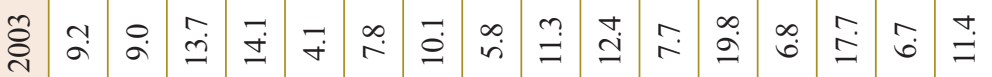

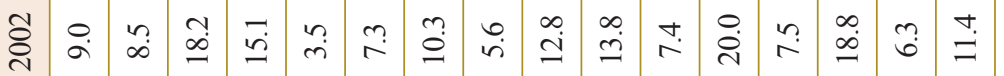

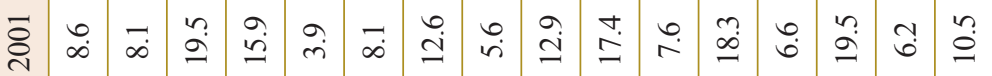

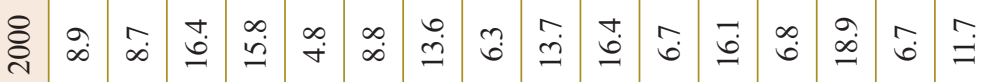

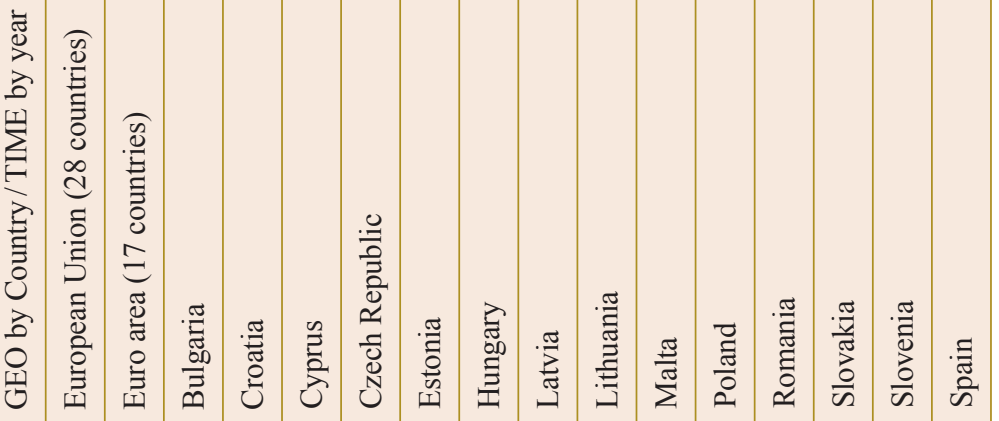

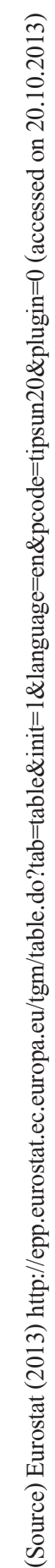




\begin{tabular}{|c|c|c|c|c|c|c|c|c|c|c|c|c|c|c|}
\hline กֶ. & $\stackrel{0}{0}$ & $\stackrel{\nabla}{\oplus}$ & $\stackrel{\circ}{i}$ & $\exists$ & & I & $\stackrel{\infty}{\rightarrow}$ & $\hat{\vec{i}}$ & $\stackrel{N}{=}$ & $\frac{n}{1}$ & $n$ & $\stackrel{\infty}{0}$ & $\stackrel{\circ}{i}$ & $\stackrel{T}{T}$ \\
\hline$\stackrel{ナ}{-}$ & $\stackrel{n}{-}$ & $\exists$ & $\stackrel{+}{i}$ & $\overrightarrow{0}$ & 9 & $\stackrel{+}{i}$ & 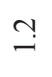 & $\stackrel{\infty}{\stackrel{\infty}{ \pm}}$ & $\stackrel{\infty}{\oplus}$ & $\stackrel{\Upsilon}{1}$ & 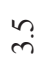 & $\ddot{m}$ & $\stackrel{+}{-}$ & $\stackrel{+}{i}$ \\
\hline$\stackrel{n}{i}$ & $\stackrel{+}{i}$ & $\stackrel{ナ}{+}$ & $\stackrel{\circ}{\circ}$ & $\stackrel{n}{-}$ & $\tilde{n}$ & 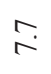 & $\stackrel{\circ}{\circ}$ & $\stackrel{\circ}{+}$ & $\stackrel{\circ}{r}$ & $\stackrel{\vartheta}{i}$ & $\stackrel{\dagger}{\oplus}$ & $\stackrel{\dot{\varphi}}{\dot{\varphi}}$ & $\ddot{0}$ & $\ddot{n}$ \\
\hline $\begin{array}{l}\infty \\
\stackrel{\sim}{i}\end{array}$ & $\begin{array}{l}\underset{T}{i} \\
\stackrel{1}{i}\end{array}$ & $\stackrel{\infty}{\dot{p}}$ & ஸุ & $\stackrel{n}{7}$ & $\stackrel{\infty}{i}$ & $\stackrel{n}{\forall}$ & $\stackrel{+}{+}$ & $\stackrel{m}{p}$ & $\begin{array}{l}0 \\
\infty \\
\infty\end{array}$ & $\begin{array}{l}\stackrel{\sim}{i} \\
i\end{array}$ & Iִ & $\stackrel{\curlyvee}{\ngtr}$ & $\stackrel{\circ}{\dot{p}}$ & ָָ \\
\hline
\end{tabular}

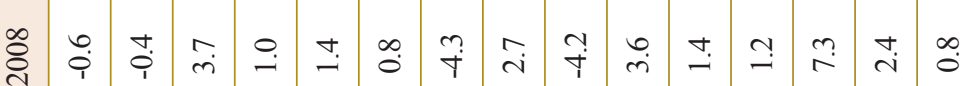

ำ.

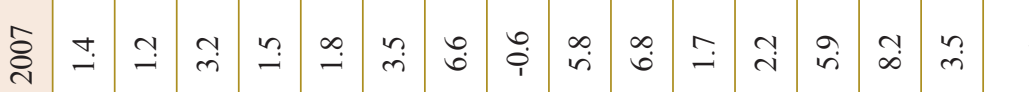




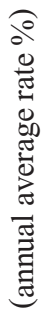

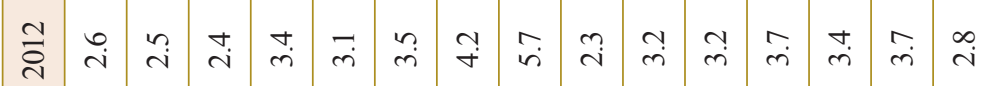

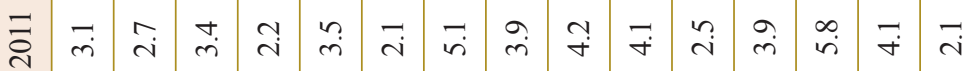

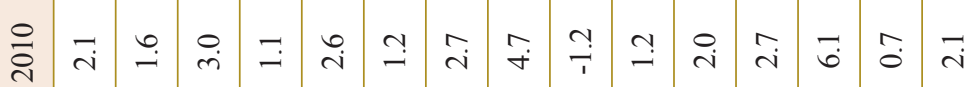

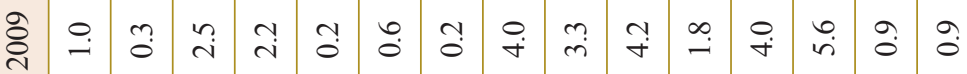

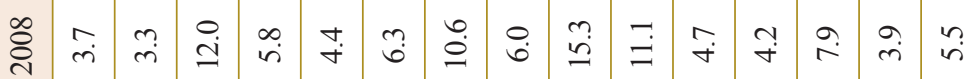

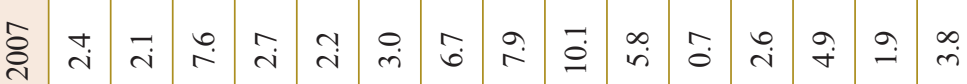

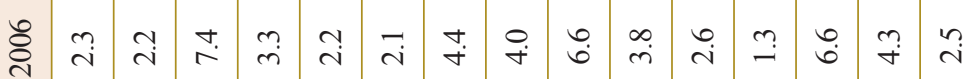

$\stackrel{\stackrel{0}{\pi}}{\check{\pi}}$

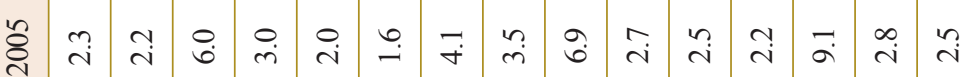

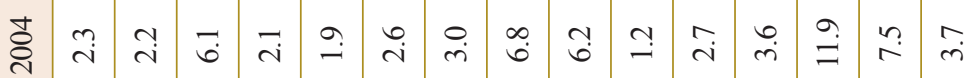

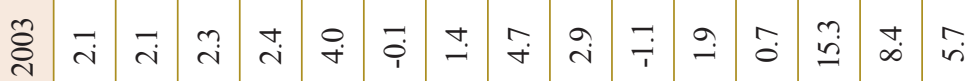

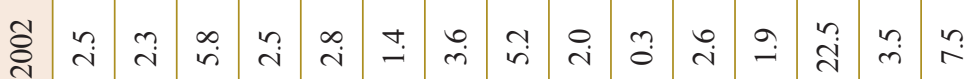

ஓ̊̊̆

ஓి

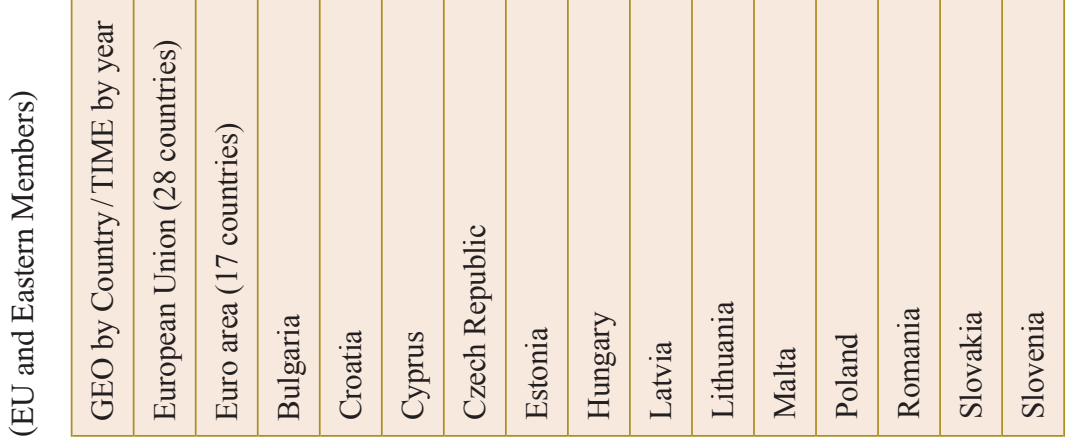

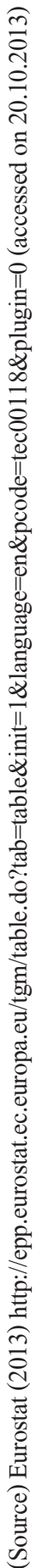




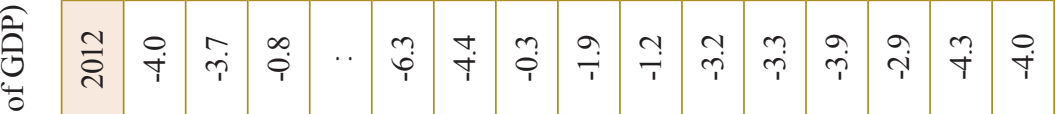

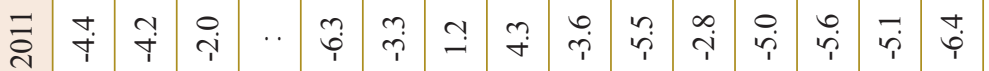
군 ठి

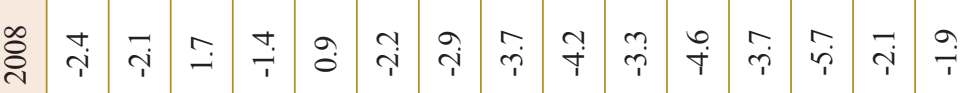
仓̊ํํ \&્ڤ

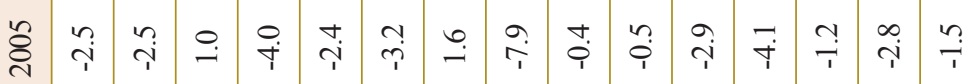

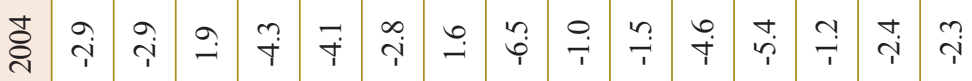

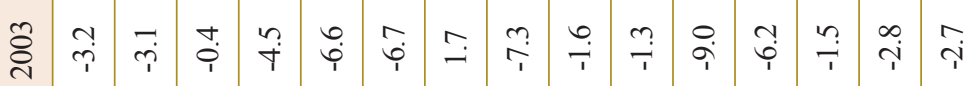
§ิ

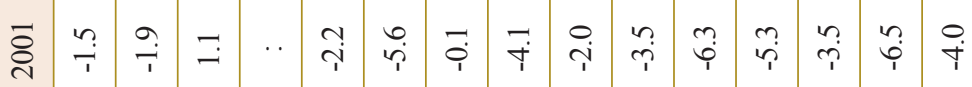

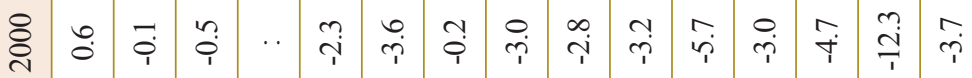

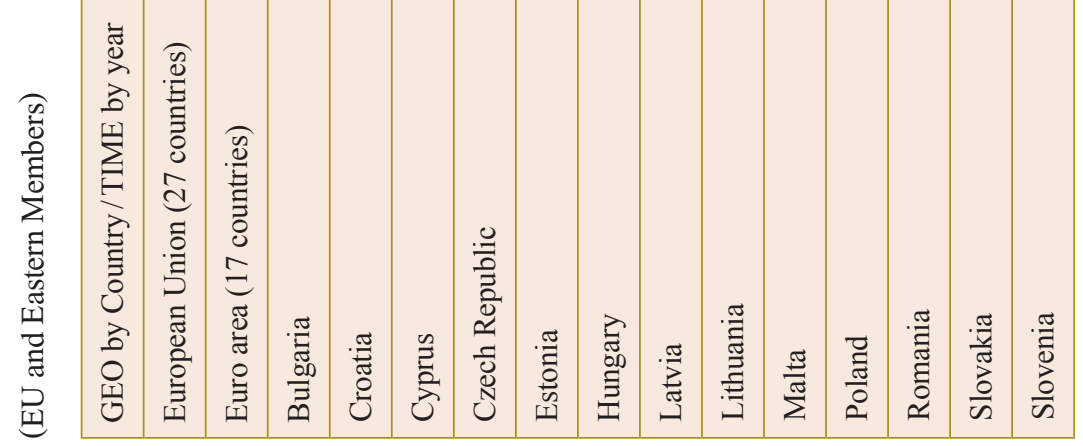




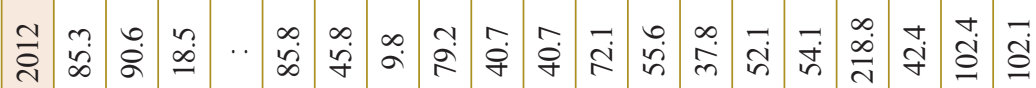

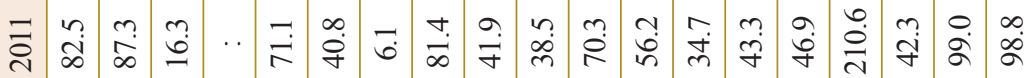

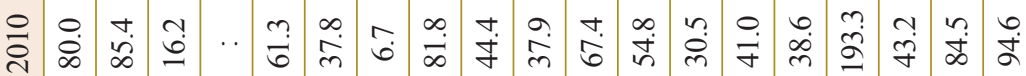

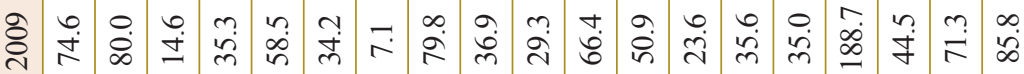

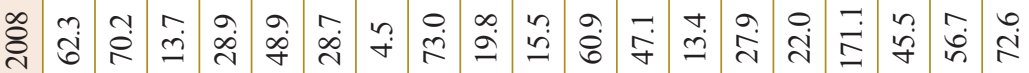

官

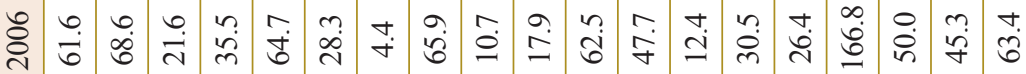

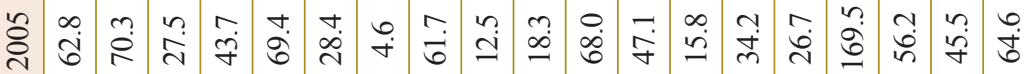

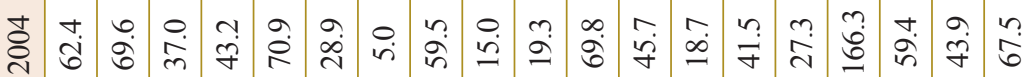

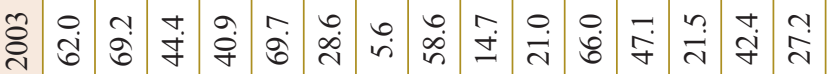

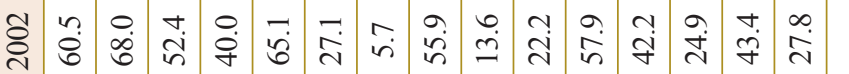

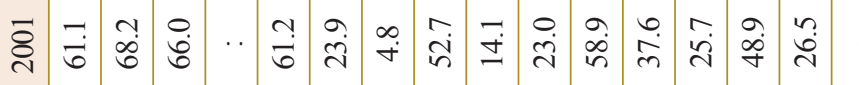

ตำ

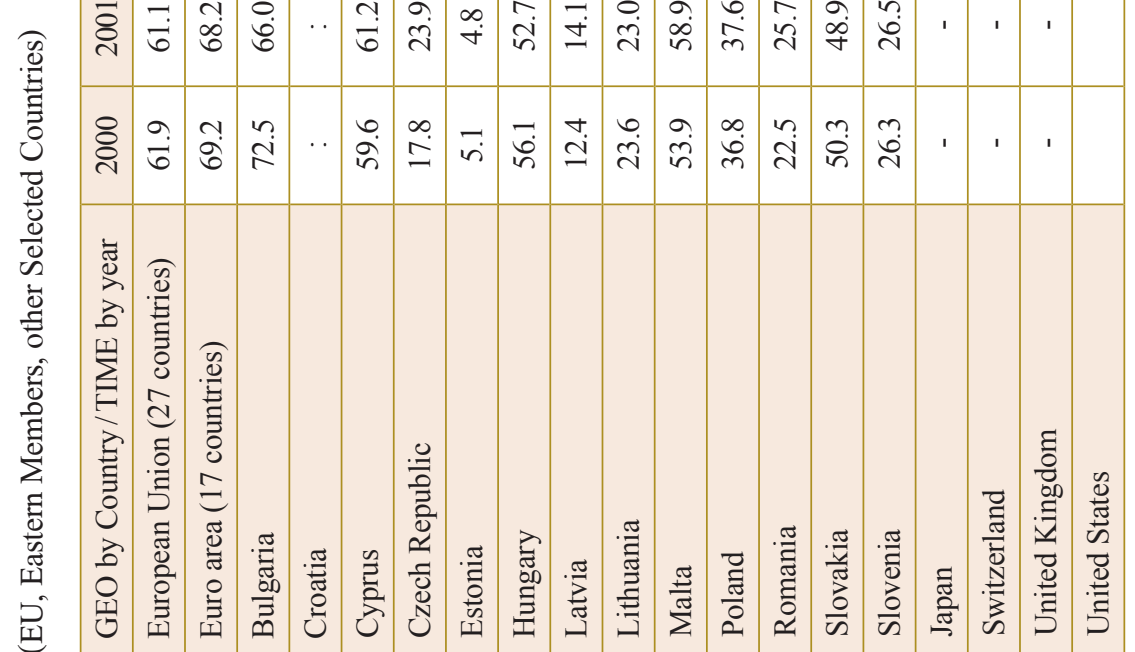

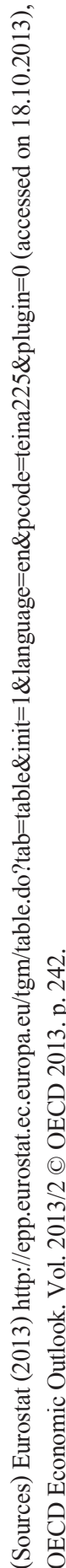




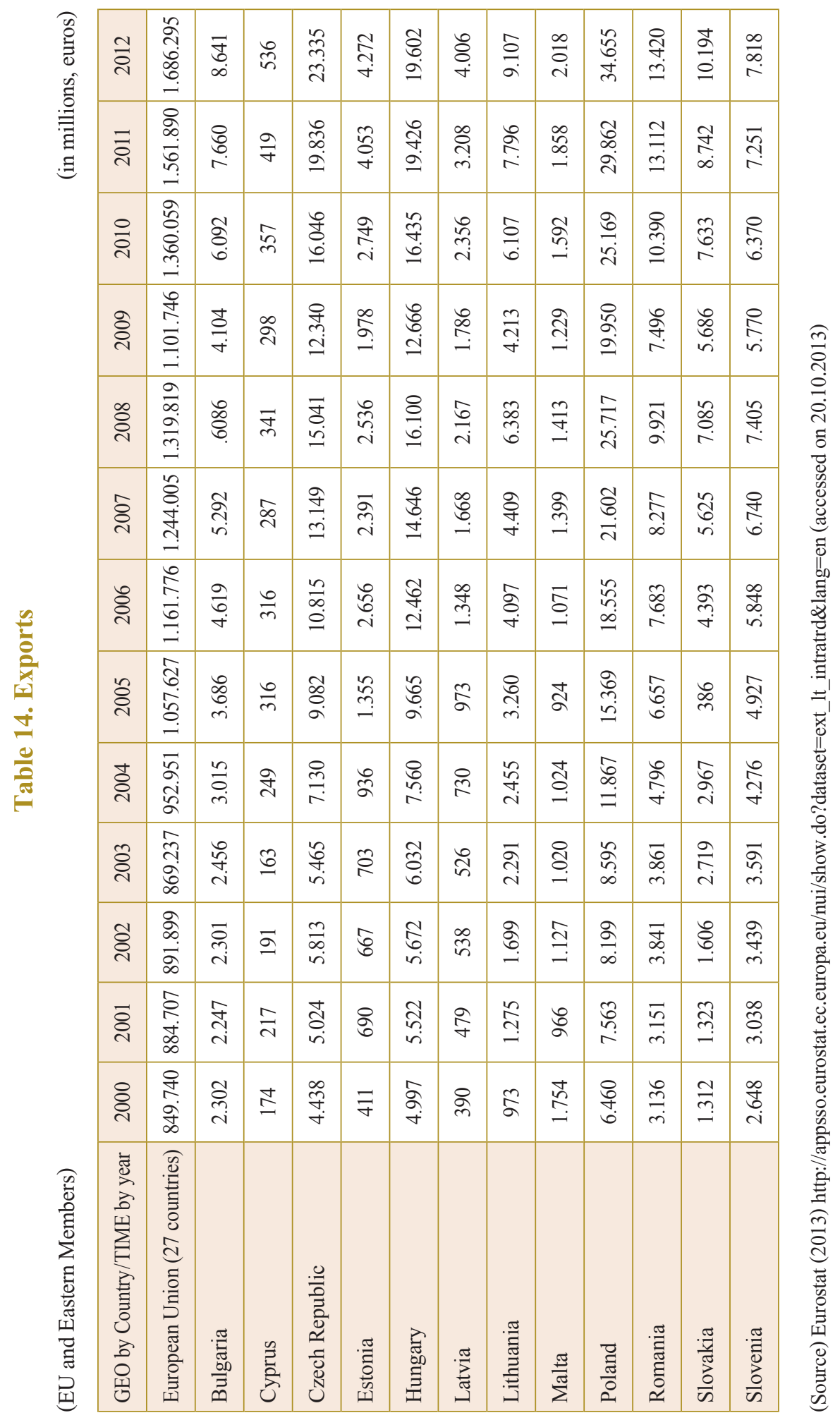




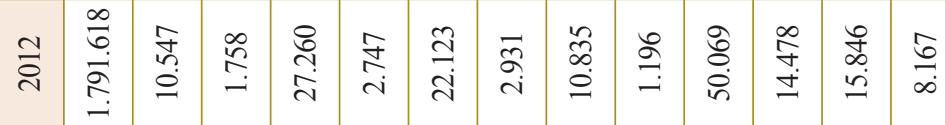

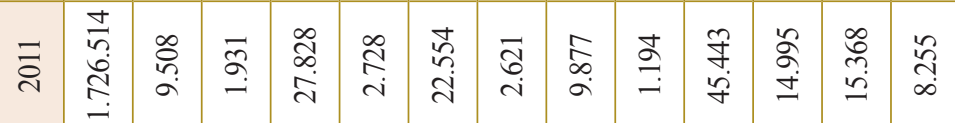

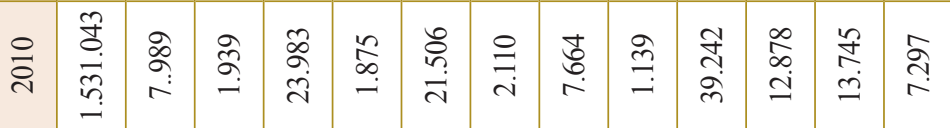

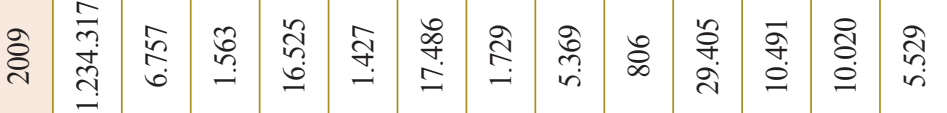

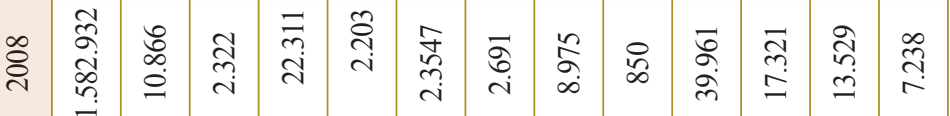

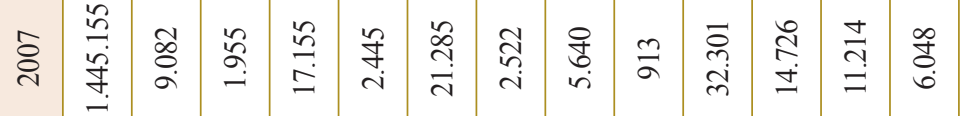

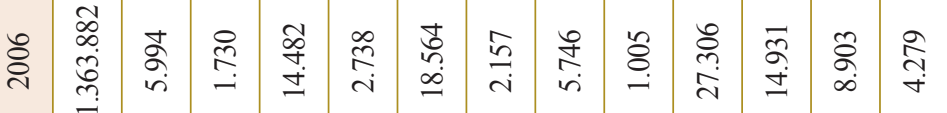

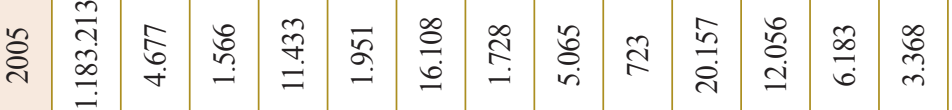

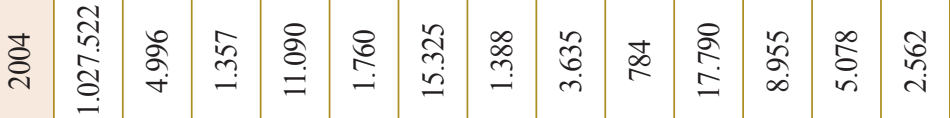

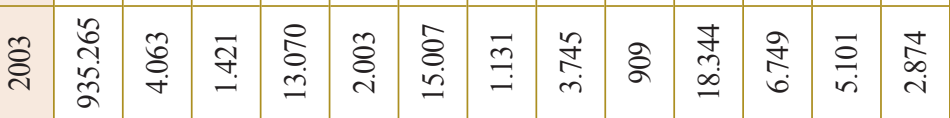

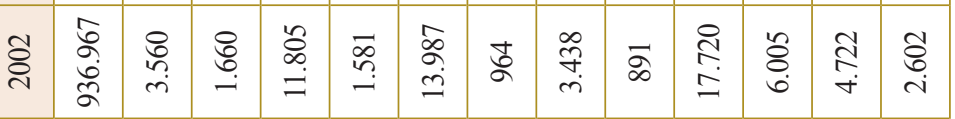

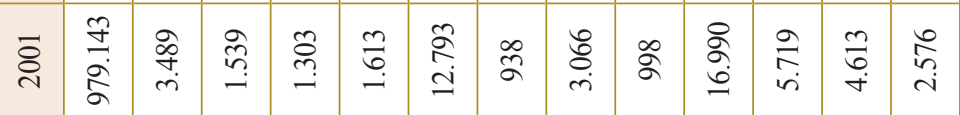

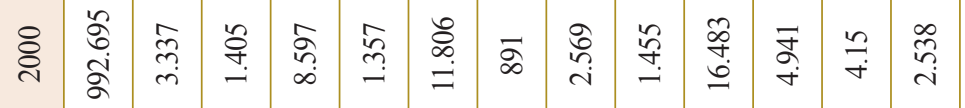

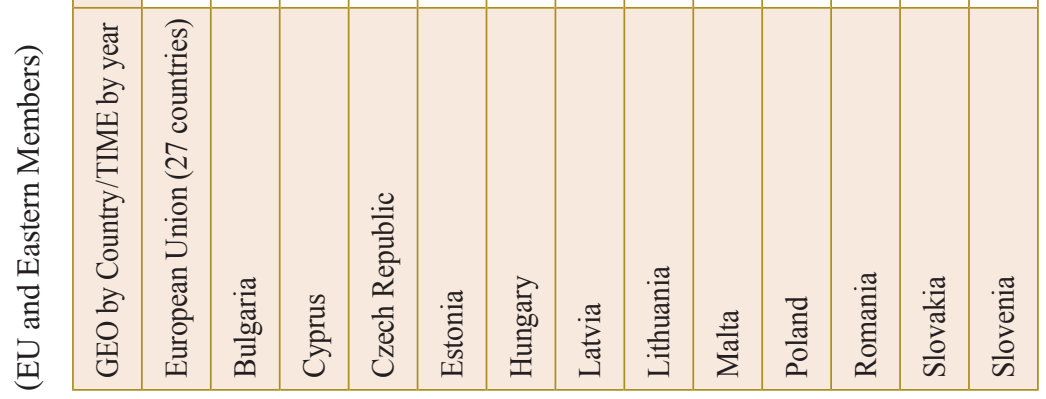




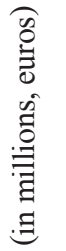

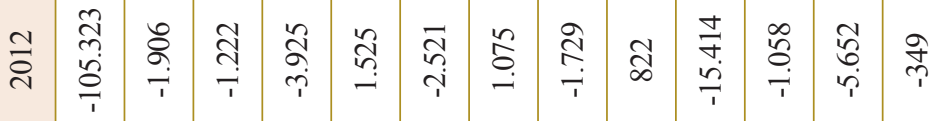

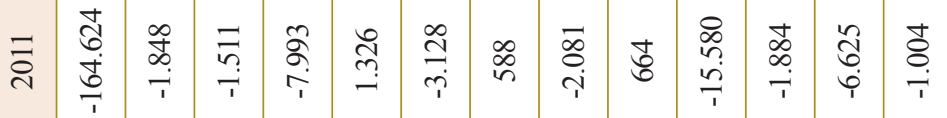

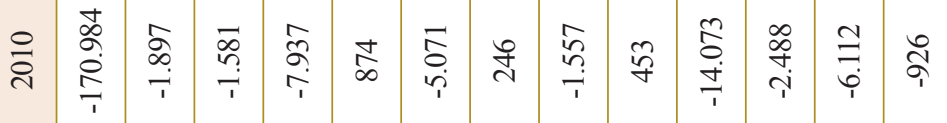

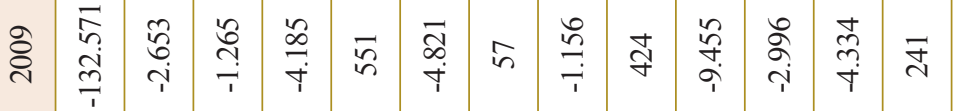

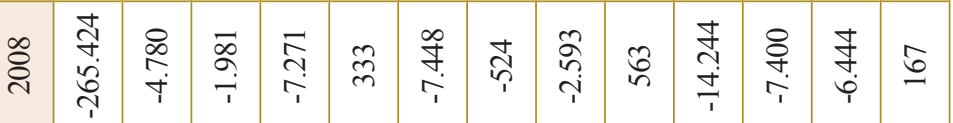

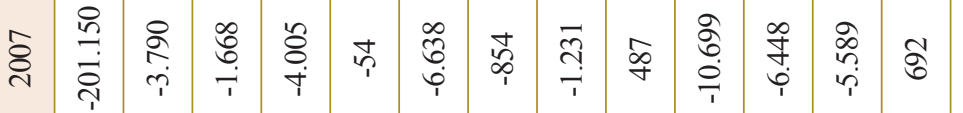

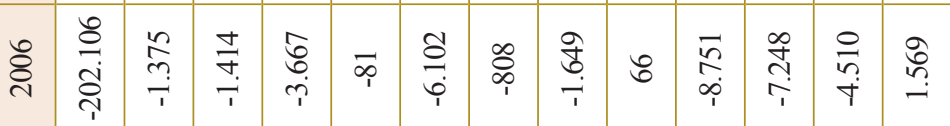

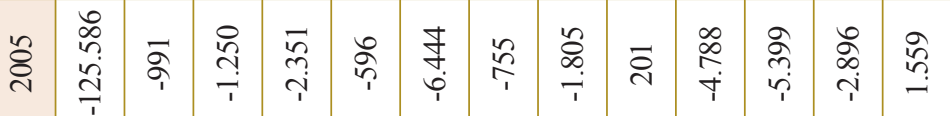

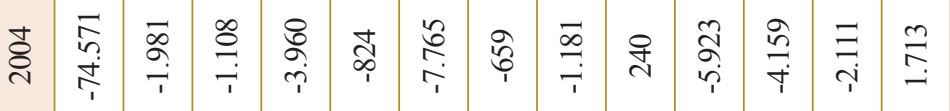

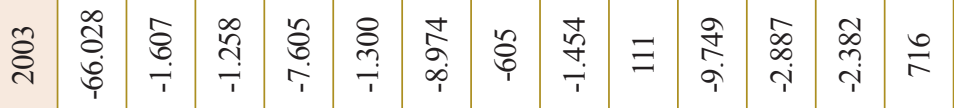

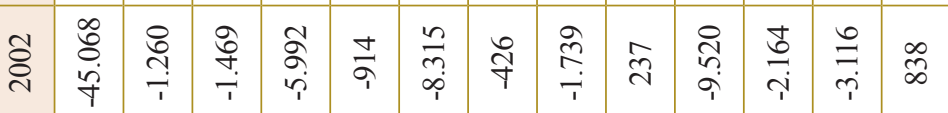

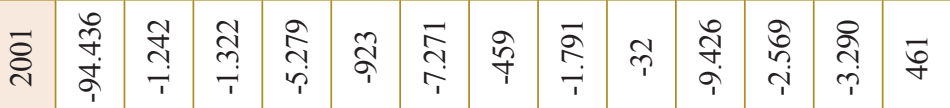

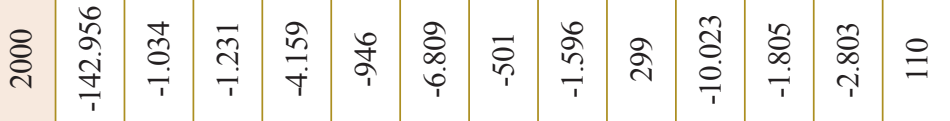

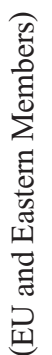

\begin{tabular}{|c|c|c|c|c|c|c|c|c|c|c|c|c|c|}
\hline $\begin{array}{l}\text { E } \\
\text { ठ } \\
\text { 己े }\end{array}$ & 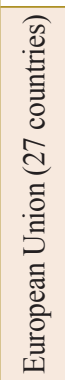 & 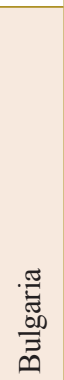 & 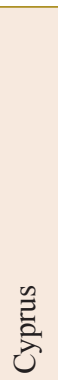 & 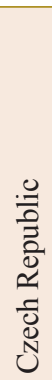 & $\stackrel{\pi}{*}$ & 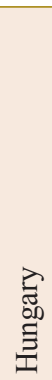 & 茎 & 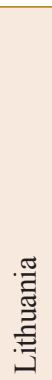 & $\frac{\pi}{\sum^{\pi}}$ & $\begin{array}{l}\vec{\Xi} \\
\frac{\text { O }}{0}\end{array}$ & 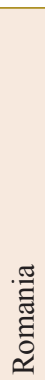 & 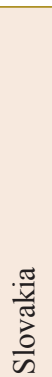 & 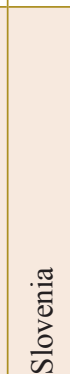 \\
\hline
\end{tabular}

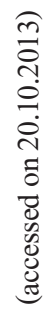

๘ี

(1)

客

言

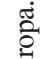

崩

:

煦

产 


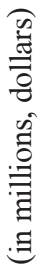

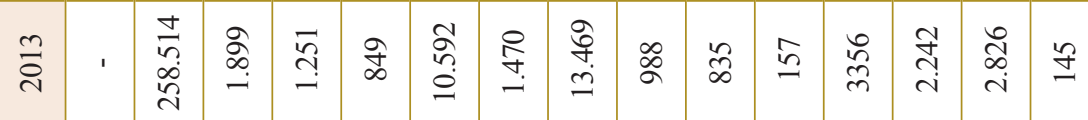

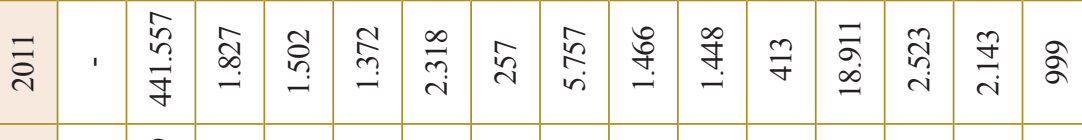

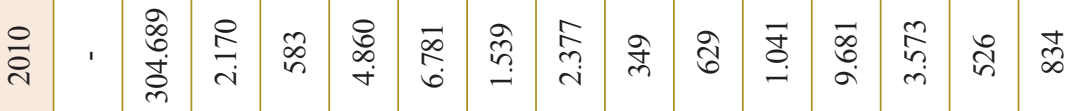

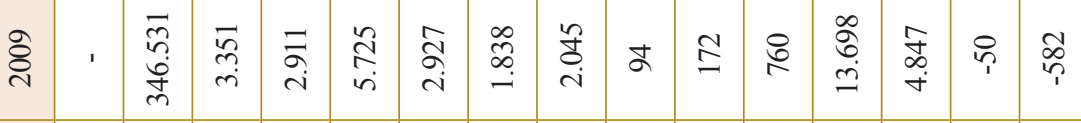

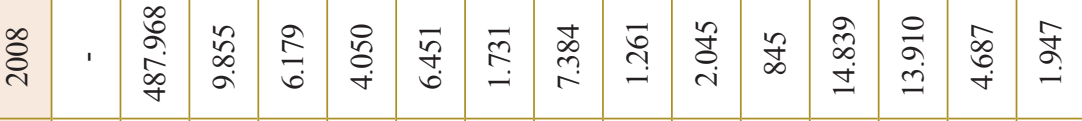

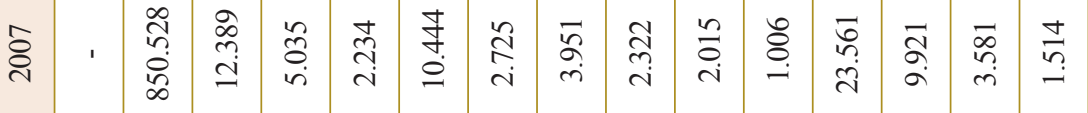

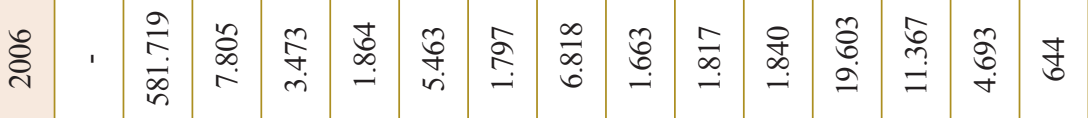

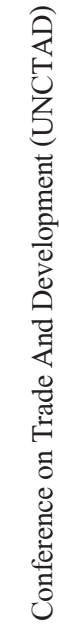

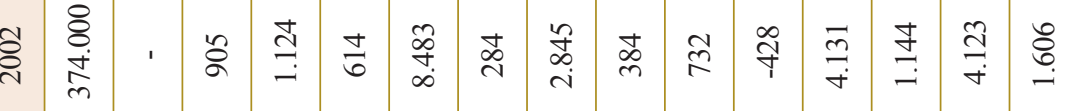

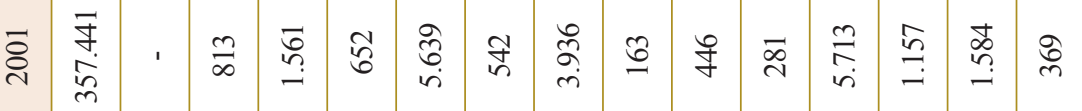

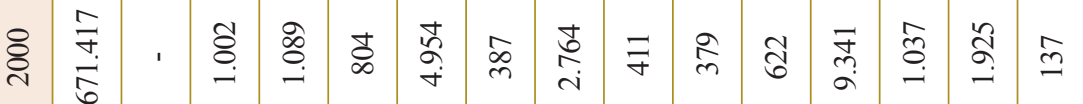

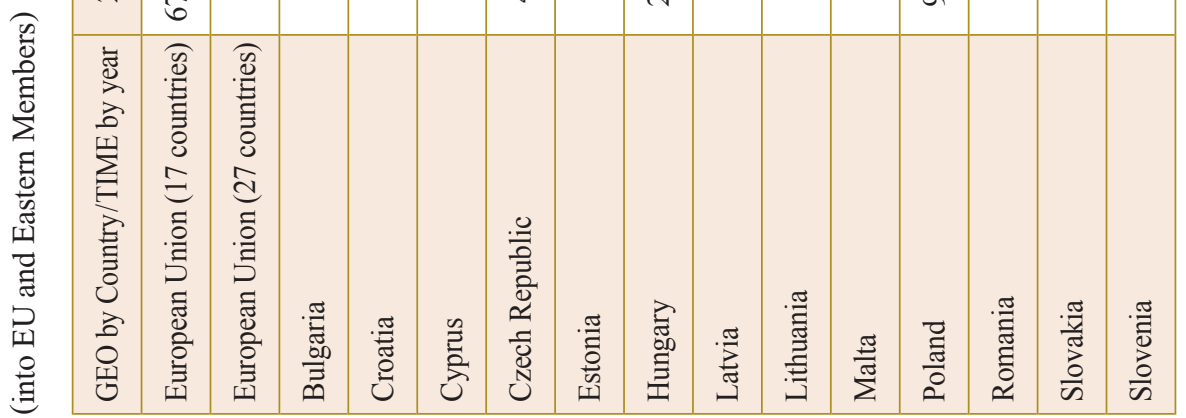




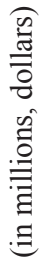

\begin{tabular}{|c|c|c|c|c|c|c|c|c|c|c|c|c|c|c|c|}
\hline 공 & ' & $\begin{array}{l}\vec{m} \\
\stackrel{m}{m}\end{array}$ & $\widehat{\widehat{N}}$ & ন & $\frac{\grave{\Xi}}{1}$ & $\stackrel{\vec{m}}{\rightarrow}$ & $\underset{\infty}{\infty}$ & $\begin{array}{l}\infty \\
\stackrel{\infty}{n} \\
0\end{array}$ & 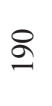 & ণิ & के & ఫે & $\stackrel{\vartheta}{f}$ & $\stackrel{\Re}{T}$ & ta \\
\hline$\overline{\vec{े}}$ & 1 & $\begin{array}{l}\text { aे } \\
\text { dें } \\
\text { nn. }\end{array}$ & $\bar{\sigma}$ & ల్ల & $\stackrel{ా}{+}$ & & 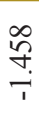 & $\begin{array}{l}\hat{\sigma} \\
\dot{+}\end{array}$ & $\widetilde{\sigma}$ & $n$ & సి & 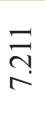 & के & ஓ & $\cong$ \\
\hline$\stackrel{\text { 융 }}{\circ}$ & ' & 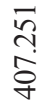 & $\stackrel{\infty}{\sim}$ & હิ & $\begin{array}{l}\stackrel{\text { }}{+} \\
\text { }\end{array}$ & શ̊ & $\stackrel{\varrho}{\simeq}$ & 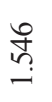 & 0 & $\stackrel{\infty}{\Xi}$ & $\hat{\infty}$ & $\underset{\stackrel{r}{r}}{\vec{r}}$ & ๙ิ & $\stackrel{\infty}{\sim}$ & $y$ \\
\hline
\end{tabular}

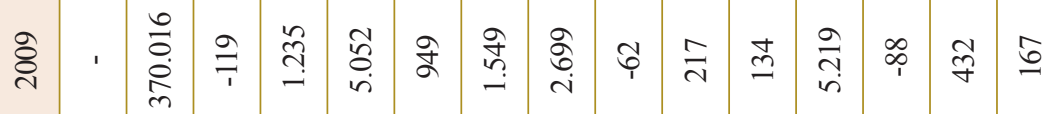

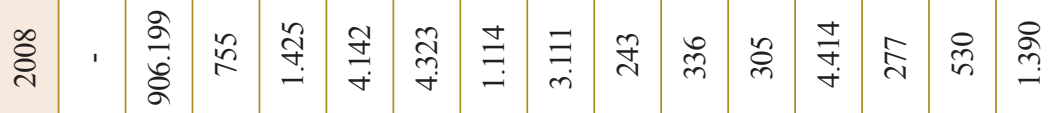

\begin{tabular}{|c|c|c|c|c|c|c|c|c|c|c|c|c|c|c|}
\hline ڤ్రి & ra & $\stackrel{\widetilde{N}}{\sim}$ & ळे & 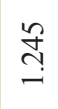 & 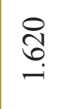 & $\stackrel{0}{\stackrel{0}{I}}$ & $\begin{array}{l}\overrightarrow{\widetilde{\sigma}} \\
\dot{r}\end{array}$ & రి & in & \pm & $\begin{array}{l}n \\
+ \\
\dot{q}\end{array}$ & $\stackrel{\curvearrowright}{\triangleq}$ & 8 & 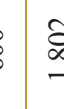 \\
\hline
\end{tabular}

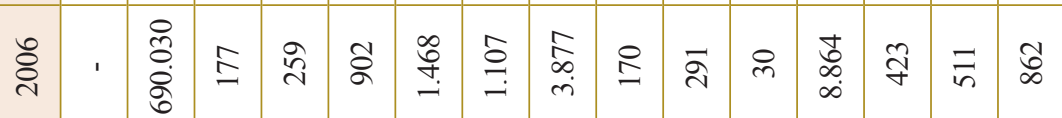

\begin{tabular}{|c|c|c|c|c|c|c|c|c|c|c|c|c|c|c|}
\hline$\hat{\wp}$ & 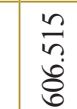 & $\stackrel{\circ}{m}$ & ते & $\stackrel{\infty}{n}$ & $\stackrel{9}{1}$ & $\overline{8}$ & $\stackrel{\Omega}{a}$ & $\stackrel{\infty}{\sim}$ & $\stackrel{0}{\stackrel{0}{0}}$ & $\vec{\imath}$ & ஓे & $\vec{p}$ & $\stackrel{n}{n}$ & 7 \\
\hline
\end{tabular}

\begin{tabular}{|c|c|c|c|c|c|c|c|c|c|c|c|c|c|c|c|}
\hline ఫ્તి & 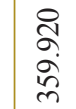 & $\stackrel{\bar{\tau}}{\bar{\tau}}$ & : & హే & $\underset{-}{\sigma}$ & $\stackrel{\infty}{\stackrel{\nu}{\nu}}$ & $\stackrel{\varrho}{\exists}$ & $\hat{\varrho}$ & $\underset{\tilde{N}}{\tilde{N}}$ & $T$ & $\hat{\imath}$ & $\Re$ & & $\vec{\uparrow}$ & $\vec{n}$ \\
\hline
\end{tabular}

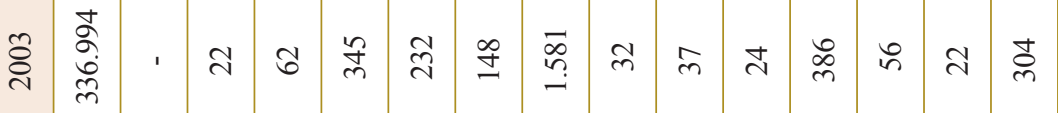

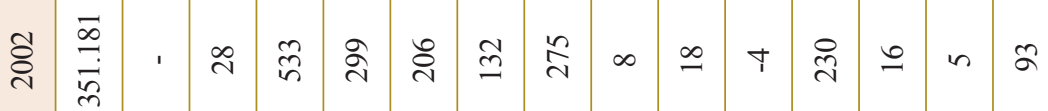

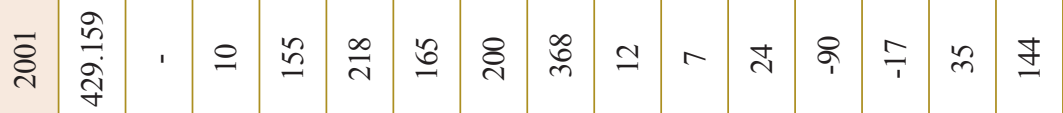

\begin{tabular}{|c|c|c|c|c|c|c|c|c|c|c|c|c|c|c|c|c|}
\hline 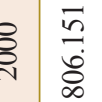 & & $m$ & & 寸 & త్రి & $\mathscr{F}$ & 3 & ๕్రి & 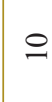 & $\nabla$ & $\approx$ & pi & $\beth$ & 7 & $\vec{\sim}$ & 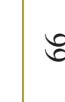 \\
\hline
\end{tabular}




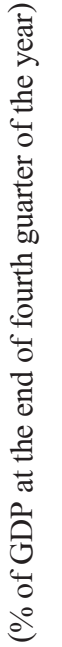

है

\begin{tabular}{|c|c|c|c|c|c|c|c|c|c|c|c|c|}
\hline$\stackrel{\widetilde{d}}{\tilde{c}}$ & $\begin{array}{l}\infty \\
\infty \\
\dot{\sigma}\end{array}$ & 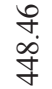 & $\stackrel{\infty}{\stackrel{\infty}{8}}$ & $\begin{array}{l}\text { qै } \\
\ddot{a}\end{array}$ & $\begin{array}{l}\overline{0} \\
\stackrel{0}{\simeq} \\
\text { I }\end{array}$ & $\begin{array}{l}\hat{n} \\
\tilde{n} \\
\end{array}$ & 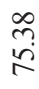 & $\begin{array}{l}\stackrel{8}{+} \\
\stackrel{+}{\circ}\end{array}$ & $\stackrel{\hat{i}}{\hat{i}}$ & $\frac{0}{2}$ & $\begin{array}{l}\stackrel{8}{\circ} \\
\stackrel{i}{i}\end{array}$ & $\begin{array}{l}\stackrel{8}{0} \\
\stackrel{\leftrightarrow}{\exists}\end{array}$ \\
\hline & 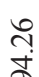 & $\begin{array}{l}\underset{丶}{+} \\
80\end{array}$ & 6 & $\begin{array}{l}\dot{\Xi} \\
\dot{J}\end{array}$ & $\vec{\sigma}$ & $\begin{array}{l}\text { ô } \\
\dot{y}\end{array}$ & $\stackrel{r}{\stackrel{2}{*}}$ & $\begin{array}{l}2 \\
\stackrel{8}{8}\end{array}$ & ָ̊n్ల & $\stackrel{F}{5}$ & $\stackrel{\infty}{\stackrel{\infty}{\circ}}$ & $\hat{\sigma}$ \\
\hline
\end{tabular}

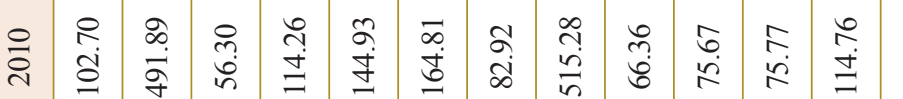

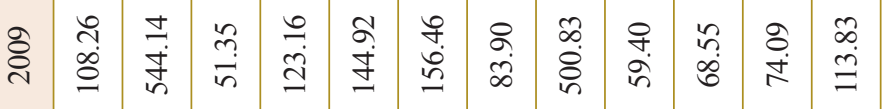

శ్

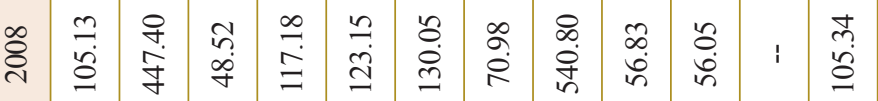

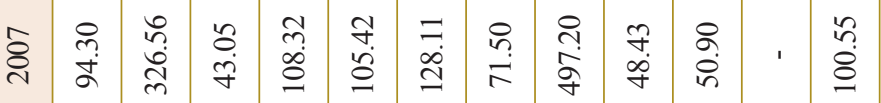

กิ

ำ.

\&

$\stackrel{\sqrt{?}}{\wedge}$

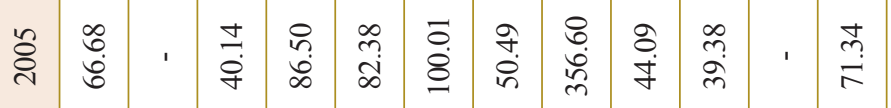

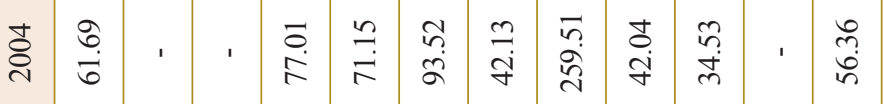

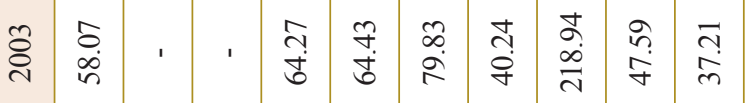

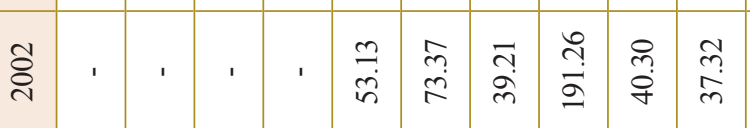

ฮั

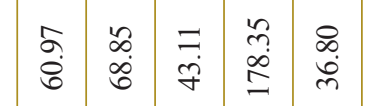

¿ุ

\begin{tabular}{|c|c|c|c|c|}
\hline $\begin{array}{l}\hat{\sigma} \\
\dot{b}\end{array}$ & $\begin{array}{l}\mathscr{1} \\
\infty \\
\infty \\
\infty\end{array}$ & $\begin{array}{l}= \\
\dot{v}\end{array}$ & $\hat{\alpha}$ & $\begin{array}{l}\stackrel{0}{0} \\
\dot{m}\end{array}$ \\
\hline
\end{tabular}

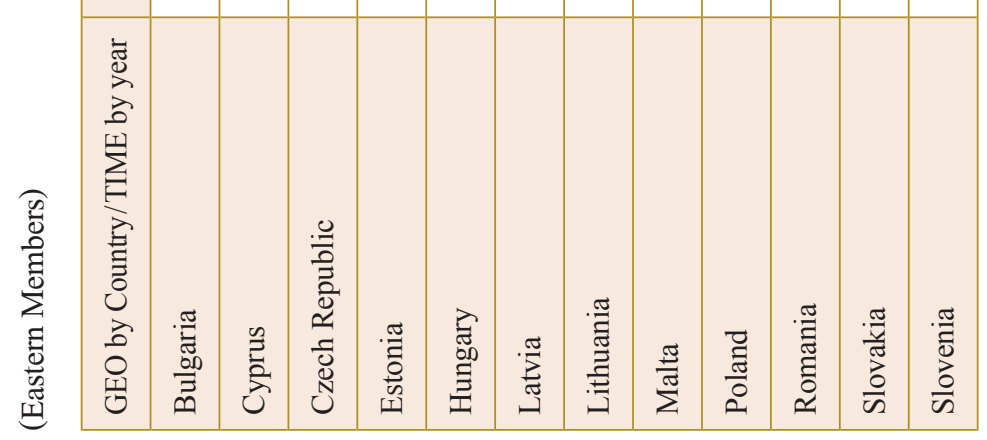




\begin{tabular}{|c|c|c|c|c|c|c|c|c|c|c|c|c|c|}
\hline $\begin{array}{l}\widehat{\vec{\Xi}} \\
\stackrel{\vec{D}}{ \pm} \\
\stackrel{ \pm}{ \pm}\end{array}$ & $\stackrel{\sim}{\check{~}}$ & 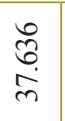 & \begin{tabular}{l}
$\hat{b}$ \\
\multirow{2}{*}{} \\
o
\end{tabular} & $\underset{\sigma}{\stackrel{\Xi}{\Xi}}$ & 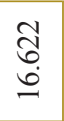 & 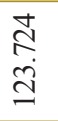 & 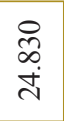 & $\begin{array}{l}\stackrel{+}{m} \\
\stackrel{n}{8}\end{array}$ & $\begin{array}{l}\stackrel{\infty}{\rightarrow} \\
\ddot{n}\end{array}$ & 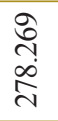 & $\begin{array}{l}\stackrel{0}{ } \\
\text { å } \\
\text { aे }\end{array}$ & $\begin{array}{l}\stackrel{o}{+} \\
\text { ó } \\
\dot{+}\end{array}$ & $\begin{array}{l}\hat{8} \\
\dot{+} \\
i\end{array}$ \\
\hline $\overrightarrow{0}$ & $\overline{\bar{c}}$ & $\begin{array}{l}\check{\curvearrowright} \\
\text { స్ } \\
0\end{array}$ & $\underset{\infty}{\vec{N}}$ & $\begin{array}{l}\stackrel{D}{ } \\
\stackrel{f}{\infty} \\
\infty \\
\infty\end{array}$ & 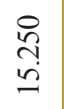 & $\begin{array}{l}\stackrel{D}{\infty} \\
\stackrel{-}{-}\end{array}$ & $\begin{array}{l}\stackrel{2}{a} \\
\text { ஸे }\end{array}$ & $\begin{array}{l}\infty \\
\stackrel{2}{0} \\
\stackrel{\text { ते }}{2}\end{array}$ & $\begin{array}{l}\text { 克 } \\
\text { m. }\end{array}$ & 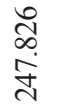 & $\begin{array}{l}\stackrel{0}{n} \\
\text { à }\end{array}$ & $\frac{8}{\stackrel{8}{q}}$ & $\begin{array}{l}\infty \\
\infty \\
\infty \\
\text { in }\end{array}$ \\
\hline 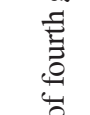 & 울 & $\begin{array}{l}\widehat{a} \\
\hat{n} \\
\text { no }\end{array}$ & $\begin{array}{l}\infty \\
\overrightarrow{0} \\
\dot{\infty} \\
\infty\end{array}$ & $\begin{array}{l}\overline{6} \\
\bar{\infty}\end{array}$ & $\begin{array}{l}\stackrel{\Im}{7} \\
\stackrel{-}{0}\end{array}$ & 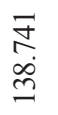 & $\begin{array}{l}\stackrel{0}{a} \\
\grave{\lambda}\end{array}$ & 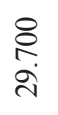 & $\begin{array}{l}\stackrel{2}{o} \\
\stackrel{m}{m}\end{array}$ & \begin{tabular}{l}
$\frac{\infty}{f}$ \\
\multirow{f}{0}{} \\
$\underset{\sim}{0}$
\end{tabular} & 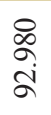 & $\underset{\stackrel{N}{i g}}{\stackrel{+}{q}}$ & $\begin{array}{l}\stackrel{\circ}{\sigma} \\
\frac{\vec{\sigma}}{\sigma}\end{array}$ \\
\hline $\begin{array}{l}\vec{E} \\
\mathbb{D} \\
\mathbb{E}\end{array}$ & ஓे & $\begin{array}{l}\vec{a} \\
\infty \\
\infty \\
m\end{array}$ & $\begin{array}{l}\frac{n}{2} \\
\frac{a}{a}\end{array}$ & $\begin{array}{l}\hat{a} \\
\stackrel{i}{i}\end{array}$ & $\begin{array}{l}\stackrel{2}{\hat{n}} \\
\end{array}$ & 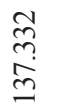 & $\begin{array}{l}\hat{D} \\
\tilde{n} \\
\tilde{N}\end{array}$ & $\begin{array}{l}\overrightarrow{\tilde{D}} \\
\infty \\
\dot{0}\end{array}$ & 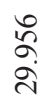 & 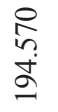 & $\frac{\stackrel{\infty}{\infty}}{\stackrel{\infty}{\infty}}$ & $\frac{\infty}{\tilde{m}}$ & 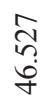 \\
\hline है & 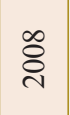 & 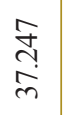 & $\underset{8}{\stackrel{8}{\circ}}$ & $\begin{array}{l}\frac{+}{f} \\
\stackrel{+}{0}\end{array}$ & 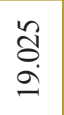 & $\begin{array}{l}\stackrel{0}{0} \\
\stackrel{n}{1} \\
\text { I }\end{array}$ & 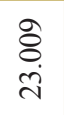 & $\begin{array}{l}\tilde{n} \\
\tilde{\imath} \\
\tilde{\lambda}\end{array}$ & 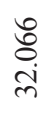 & 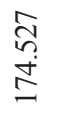 & $\frac{m}{i}$ & 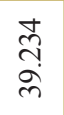 & ' \\
\hline 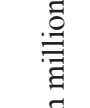 & હ્ণ & $\begin{array}{l}\bar{a} \\
\stackrel{0}{0}\end{array}$ & $\frac{a}{\vec{a}}$ & $\begin{array}{l}\stackrel{\vec{\lambda}}{n} \\
\stackrel{n}{n}\end{array}$ & 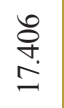 & $\begin{array}{l}\tilde{\infty} \\
\infty \\
\tilde{0}\end{array}$ & \begin{tabular}{l}
\multirow{f}{*}{} \\
$\stackrel{2}{2}$ \\
$\stackrel{2}{2}$
\end{tabular} & $\begin{array}{l}\vec{\otimes} \\
\stackrel{\Delta}{\sim}\end{array}$ & $\frac{2}{\stackrel{\infty}{\sim}}$ & 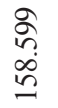 & $\begin{array}{l}\text { o } \\
80 \\
\infty \\
\infty\end{array}$ & 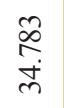 & ' \\
\hline & 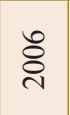 & $\begin{array}{l}\vec{a} \\
\dot{0} \\
\dot{i}\end{array}$ & $\begin{array}{l}\stackrel{\infty}{8} \\
\dot{\sigma} \\
\dot{\gamma}\end{array}$ & $\begin{array}{l}\stackrel{+}{o} \\
\stackrel{0}{\infty} \\
\dot{\sigma}\end{array}$ & 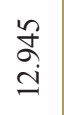 & $\begin{array}{l}\mathbb{J} \\
\mathbb{0} \\
\infty \\
\infty\end{array}$ & 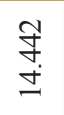 & $\begin{array}{l}\stackrel{n}{\sim} \\
\underset{\infty}{\infty}\end{array}$ & 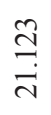 & $\begin{array}{l}n \\
\infty \\
\infty \\
\infty \\
\stackrel{\bigcup}{\beth}\end{array}$ & $\frac{\infty}{\stackrel{Ð}{\forall}}$ & $\begin{array}{l}\infty \\
\ddot{\delta} \\
\stackrel{+}{\sim}\end{array}$ & ' \\
\hline & $\stackrel{\overbrace{}}{\stackrel{\nu}{े}}$ & $\begin{array}{l} \pm \\
0 \\
n \\
n \\
n\end{array}$ & ' & $\frac{\widetilde{Z}}{\stackrel{\vartheta}{\vartheta}}$ & 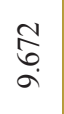 & 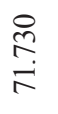 & $\begin{array}{l}\infty \\
\infty \\
0 \\
0\end{array}$ & $\begin{array}{l}\text { ડે } \\
\text { త̀ }\end{array}$ & $\begin{array}{l}n \\
\infty \\
\\
\end{array}$ & $\begin{array}{l}\stackrel{N}{N} \\
\stackrel{N}{=}\end{array}$ & $\begin{array}{l}\text { đิ } \\
\text { oे }\end{array}$ & $\begin{array}{l}\hat{a} \\
\text { cे } \\
\text { ì }\end{array}$ & ' \\
\hline & ఫ্ণ & $\begin{array}{l}\overrightarrow{0} \\
\stackrel{n}{\jmath}\end{array}$ & ' & , & $\underset{r}{\stackrel{r}{r}}$ & $\begin{array}{l}\stackrel{n}{\hat{~}} \\
\stackrel{n}{n}\end{array}$ & $\underset{\infty}{\infty}$ & ঞ̊. & 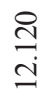 & 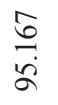 & 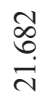 & $\begin{array}{l}\tilde{m} \\
\tilde{m} \\
\stackrel{n}{n}\end{array}$ & ' \\
\hline & ڤి & $\begin{array}{l}+ \\
\text { ర్ } \\
0 \\
0\end{array}$ & ' & , & $\begin{array}{l}\dot{8} \\
\stackrel{d}{ } \\
\dot{r}\end{array}$ & 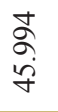 & $\vec{\sigma}$ & $\begin{array}{l}\overrightarrow{0} \\
\stackrel{\overbrace{}}{r}\end{array}$ & $\stackrel{n}{n}$ & 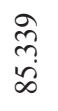 & $\begin{array}{l}\vec{\curvearrowleft} \\
\stackrel{0}{=} \\
\end{array}$ & ' & ' \\
\hline & ઠิ & ' & 1 & ' & 1 & 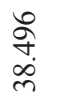 & $\begin{array}{l}\text { in } \\
\text { in }\end{array}$ & $\underset{b}{\vec{\infty}}$ & $\begin{array}{l}\stackrel{\partial}{\infty} \\
\infty \\
\infty\end{array}$ & $\frac{\grave{\delta}}{\text { ¿े }}$ & $\begin{array}{l}\stackrel{0}{ \pm} \\
6 \\
0\end{array}$ & ' & ' \\
\hline & $\overrightarrow{\grave{d}}$ & ' & ' & ' & 1 & $\begin{array}{l}\text { 을 } \\
\stackrel{n}{n} \\
m\end{array}$ & 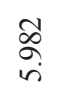 & 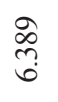 & $\stackrel{\partial}{\partial}$ & $\begin{array}{l}\vec{\infty} \\
\stackrel{\infty}{\infty} \\
\infty\end{array}$ & ' & ' & ' \\
\hline & ষ্ণ & ' & ' & ' & 1 & $\begin{array}{l}\mathbb{J} \\
\stackrel{n}{n} \\
\text { nn }\end{array}$ & $\frac{\infty}{\vec{n}}$ & $\begin{array}{l}\overrightarrow{8} \\
\ddot{i}\end{array}$ & $\begin{array}{l}\infty \\
\infty \\
\infty \\
\infty\end{array}$ & $\begin{array}{l}\stackrel{i}{n} \\
\stackrel{i}{i}\end{array}$ & ' & ' & ' \\
\hline 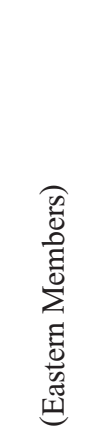 & 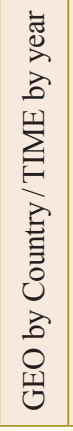 & 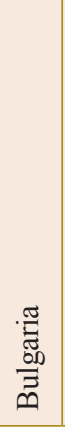 & 总 & 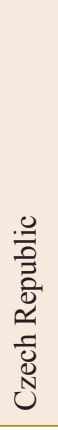 & 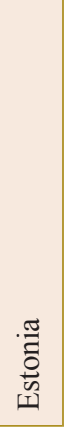 & 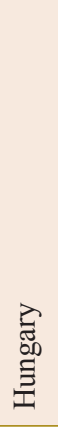 & $\begin{array}{l}\stackrel{\widetilde{a}}{\Xi} \\
\stackrel{\Xi}{\Xi} \\
\stackrel{\Xi}{コ}\end{array}$ & 茎 & $\frac{\pi}{\sum^{\pi}}$ & $\begin{array}{l}\overrightarrow{\vec{E}} \\
\text { 흉 } \\
\stackrel{2}{2}\end{array}$ & 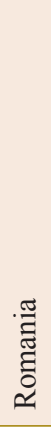 & $\begin{array}{l}\cdot \frac{\pi}{\pi} \\
\frac{0}{\pi} \\
\frac{\partial}{\sim}\end{array}$ & $\begin{array}{l}\frac{\pi}{0} \\
\frac{\pi}{\pi} \\
\frac{\partial}{\pi} \\
n\end{array}$ \\
\hline
\end{tabular}




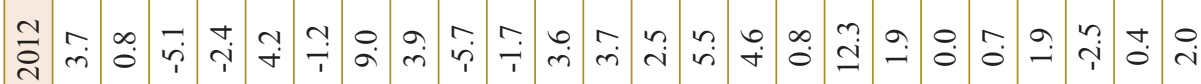

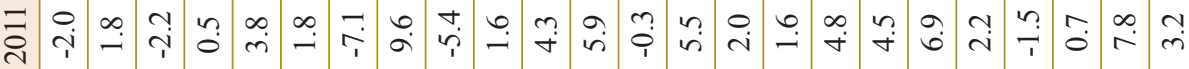

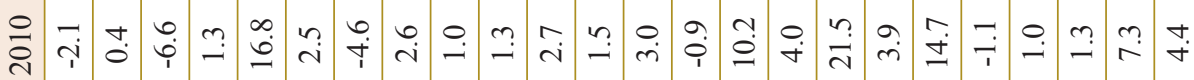

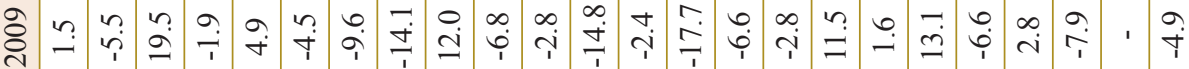

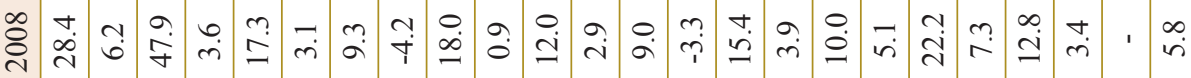

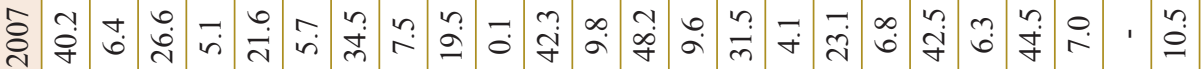

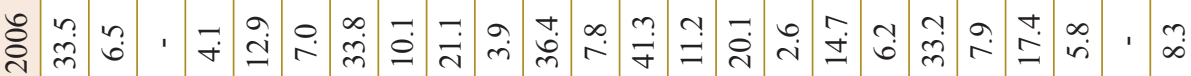

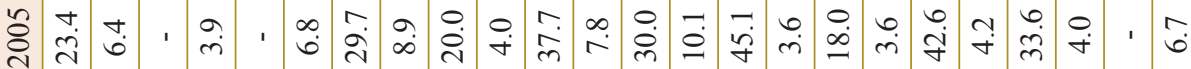

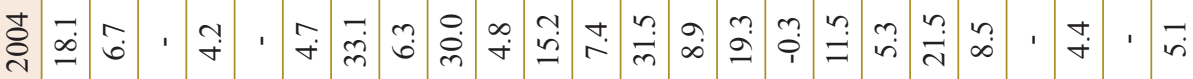

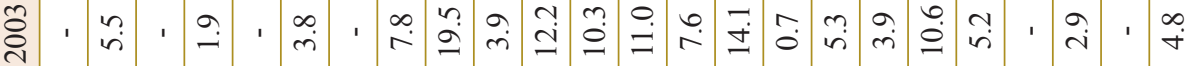

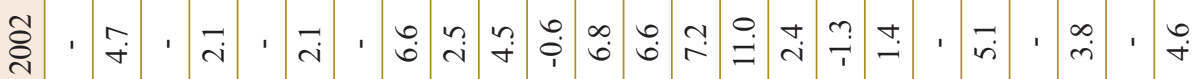

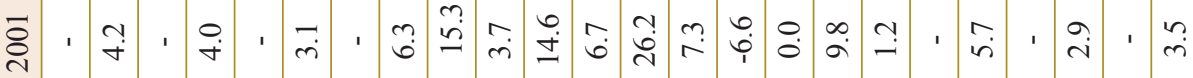

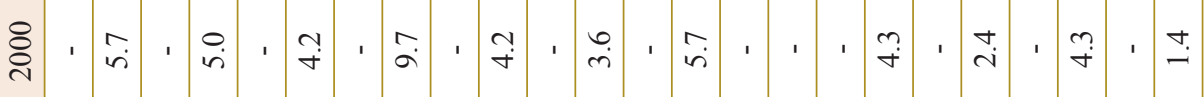

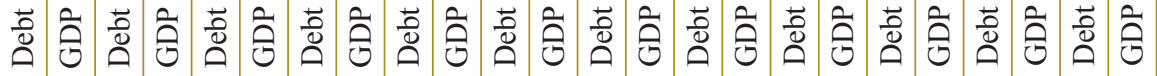

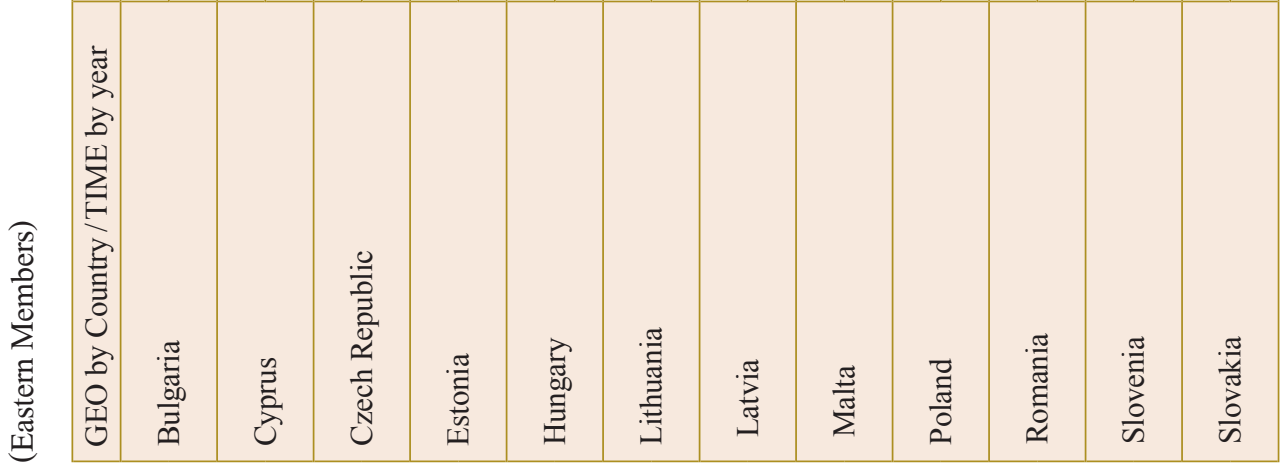

